This document was prepared in conjunction with work accomplished under Contract No. DE-AC09-96SR18500 with the U. S. Department of Energy.

\title{
DISCLAIMER
}

This report was prepared as an account of work sponsored by an agency of the United States Government. Neither the United States Government nor any agency thereof, nor any of their employees, nor any of their contractors, subcontractors or their employees, makes any warranty, express or implied, or assumes any legal liability or responsibility for the accuracy, completeness, or any third party's use or the results of such use of any information, apparatus, product, or process disclosed, or represents that its use would not infringe privately owned rights. Reference herein to any specific commercial product, process, or service by trade name, trademark, manufacturer, or otherwise, does not necessarily constitute or imply its endorsement, recommendation, or favoring by the United States Government or any agency thereof or its contractors or subcontractors. The views and opinions of authors expressed herein do not necessarily state or reflect those of the United States Government or any agency thereof. 


\section{CHARACTERIZATION AND DISSOLUTION TEST RESULTS FOR THE JANUARY 2005 DWPF OFF GAS CONDENSATE TANK SAMPLES (U)}

M. S. Hay

T.L. Fellinger

April 8, 2005

Immobilization Technology Section Savannah River National Laboratory Aiken, SC 29808

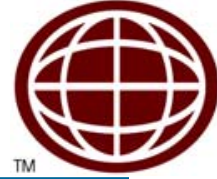

Prepared for the U.S. Department of Energy Under Contract Number DEAC09-96SR18500 


\title{
DISCLAIMER
}

This report was prepared by Westinghouse Savannah River Company (WSRC) for the United States Department of Energy under Contract No. DE-AC09-96SR18500 and is an account of work performed under that contract. Neither the United States Department of Energy, nor WSRC, nor any of their employees makes any warranty, expressed or implied, or assumes any legal liability or responsibility for the accuracy, completeness, or usefulness, of any information, apparatus, or product or process disclosed herein or represents that its use will not infringe privately owned rights. Reference herein to any specific commercial product, process, or service by trademark, name, manufacturer or otherwise does not necessarily constitute or imply endorsement, recommendation, or favoring of same by WSRC or by the United States Government or any agency thereof. The views and opinions of the authors expressed herein do not necessarily state or reflect those of the United States Government or any agency thereof.

\author{
Printed in the United States of America \\ Prepared For \\ U.S. Department of Energy
}


Key Words: $D W P F, O G C T$,

Characterization, Dissolution Testing

Retention: Permanent

\section{CHARACTERIZATION AND DISSOLUTION TEST RESULTS FOR THE JANUARY 2005 DWPF OFF GAS CONDENSATE TANK SAMPLES (U)}

M. S. Hay

T.L. Fellinger

April 8, 2005

Immobilization Technology Section Savannah River National Laboratory Aiken, SC 29808 


\section{REVIEWS AND APPROVALS}

\section{AUTHORS:}

T.L. Fellinger, Immobilization Technology Section

Date

M. S. Hay, Waste Processing Technology Section

Date

\section{TECHNICAL REVIEWER:}

N.E. Bibler, Immobilization Technology Section

Date

\section{APPROVERS}

E. W. Holtzscheiter, Manager, Immobilization Technology Section

Date

S. L. Marra, Manager, Glass Formulation \& Process Development

Date

J. E. Occhipinti, Manager, DWPF Process Engineering

Date 


\section{EXECUTIVE SUMMARY}

The Off Gas Condensate Tank (OGCT) at the Defense Waste Processing Facility (DWPF) collects the condensate from the off-gas system of the melter. The condensate stream contains entrained solids that collect in the OGCT. Water from the OGCT is re-circulated to the Steam Atomized Scrubber and quencher and may provide a mechanism for re-introducing the particulates into the off-gas system. These particulates are thought to be responsible for plugging the downstream High Efficiency Mist Eliminator filters. Therefore, the OGCT needs to be periodically cleaned to remove the build-up of entrained solids. Currently, the OGCT is cleaned by adding nominally $12 \mathrm{wt} \%$ nitric acid with agitation to slurry the solids from the tank. Samples from the OGCT were sent to the Savannah River National Lab (SRNL) for characterization and to conduct tests to determine the optimum nitric acid concentration and residence time to allow more effective cleaning of the OGCT. This report summarizes the chemical and radionuclide results and the results from the nitric acid dissolution testing at $50 \%$ and $12 \%$ obtained for the OGCT sample. Below is a summary of the observations, conclusions and recommendations based on these OGCT, samples.

\section{Observations and Conclusions:}

- The OGCT samples contained visible brown solids that appeared to be made up of fine particulates that settled very slowly. However, during the mixing and sampling process, the presence of fast settling particulates was also clearly indicated.

- The entrained solids in the OGCT sample are composed of mainly $\mathrm{Fe}, \mathrm{Si}, \mathrm{Mn}, \mathrm{Al}, \mathrm{Ni}$, and $\mathrm{Mg}$ with Fe being the dominant component. The results of the characterization show slight differences when compared to a previous OGCT sample ${ }^{1}$, however, the major components of both samples are similar.

- The results for the Contained X-Ray Diffraction (CXRD) indicated that two forms of Fe (hematite and magnetite) are present in the solids of the OGCT sample. These samples were compared to previously published results by C.M. Jantzen for samples from the Scaled Glass Melter Off-Gas Condensate Tank (SGMOGCT) ${ }^{2}$. C.M. Jantzen's results indicated spinel and $\mathrm{SiO}_{2}$ as the main components of the solids from the SGMOGCT.

- Contained Scanning Electron Microscopy (CSEM) results for the OGCT solids were consistent with C.M. Jantzen's analysis of the SGMOGCT results. Deposits rich in Si as well as spinel forming elements (Fe, $\mathrm{Al}, \mathrm{Mn}$, and $\mathrm{Ni}$ ) were identified in the OGCT samples.

- For both nitric acid dissolutions cases (50\% and 12\%), some elements appear to be rapidly increasing in concentration in the supernate, such as Fe and Mn, and others appear to be dissolving slowly such as $\mathrm{Na}$ and $\mathrm{Si}$. The dissolution of these elements is dependant on their chemical form.

- The residence time and the concentration of the nitric acid used for the OGCT cleaning procedure are important variables. Extending the residence time from 8 hours to 24 hours, results in the dissolution of more of the OGCT solids. Increasing the nitric acid concentration from $12 \%$ to $50 \%$ dissolved $45 \%$ (average of seven elements) more of the OGCT solids. 


\section{Recommendation:}

- In order to dissolve more of the OGCT solids during a tank cleanout, it is recommended that the nitric acid concentration be increased to $39.6 \mathrm{wt}$. \% and the residence time to 24 hours. If it is not desired to change the nitric acid concentration, then the residence time should be extended to 24 hours to dissolve as much of the OGCT solids as possible. 


\section{TABLE OF CONTENTS}

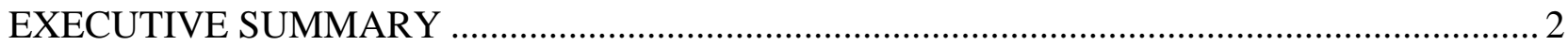

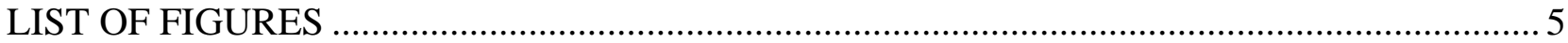

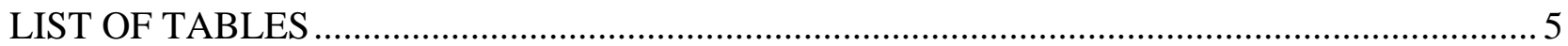

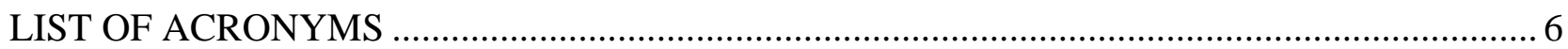

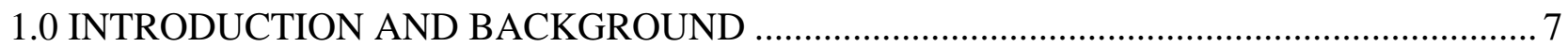

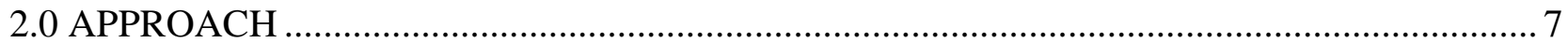

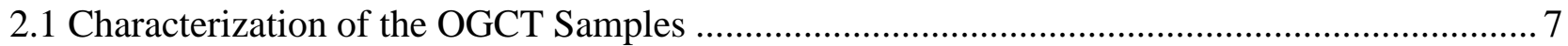

2.2 Brief Description of Analyses Performed for the OGCT ................................................... 8

2.3 Demonstration of the OGCT Tank Cleaning Method with Different Concentrations of Nitric

Acid Solutions

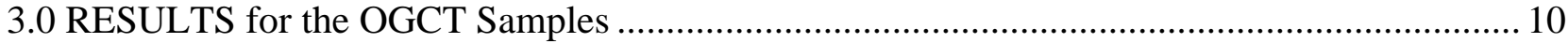

3.1 Summary of Analytical Data Obtained for the OGCT Samples............................................. 10

3.2 Contained X-Ray Diffraction (CXRD) and Contained Scanning Electron Microscopy

(CSEM) Results for Filtered Samples of the OGCT Solids ................................................ 12

3.3 ICP-ES Results of the OGCT Tank Cleaning Method Tests ............................................... 16

3.4 Amount of Al, Fe, Mg, Mn, Na, Ni, and Si Dissolved During the 12 wt.\% and 50 wt.\% Nitric

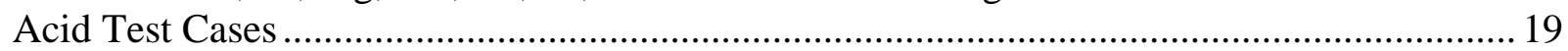

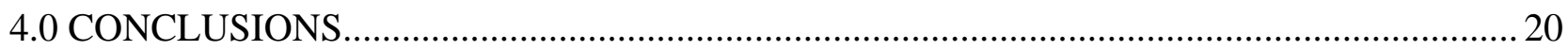

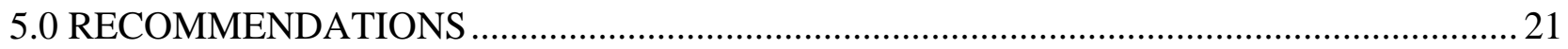

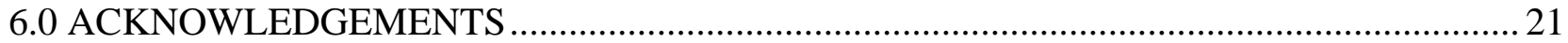

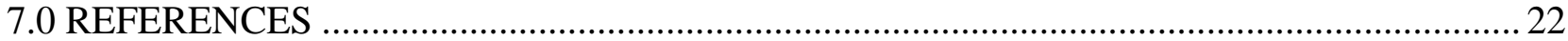

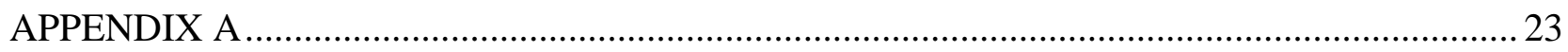

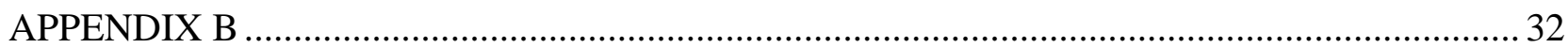




\section{LIST OF FIGURES}

Figure 1 - Spectra from CXRD Analyses of the OGCT Sample.......................................................... 13

Figure 2 - CSEM Picture of the OGCT Solids (Magnification of 50x) ................................................... 13

Figure 3 - CSEM Picture of the OGCT Solids (Magnification of 240x) ................................................. 14

Figure 4 - Spectrum for Spot 1 Identified in Figure 3 for the OGCT Solids............................................ 14

Figure 5 - Spectrum for Spot 2 Identified in Figure 3 for the OGCT Solids........................................... 15

Figure 6 - Comparison of the Concentration Data for Al, Mg, and Mn taken at Time Zero, 2 Hour, 8 Hour, and 24 Hour for the 12 wt.\% and 50 wt.\% Nitric Acid Cases .......................................18

Figure 7 - Comparison of the Concentration Data for Na, Ni, and Si taken at Time Zero, 2 Hour, 8 Hour, and 24 Hour for the 12 wt.\% and 50 wt.\% Nitric Acid Cases ................................................ 18

Figure 8 - Comparison of the Concentration Data for Fe taken at Time Zero, 2 Hour, 8 Hour, and 24 Hour for the 12 wt. \% and 50 wt. \% Nitric Acid Cases .................................................................. 19

Figure B - 1 CSEM Picture of the OGCT Solids (Magnification of 2000x) …........................................ 33

Figure B - 2 Spectrum for Spot 1 Identified in Figure B - 1 for the OGCT Solids.................................... 33

Figure B - 3 CSEM Picture of the OGCT Solids (Magnification of 150x) ............................................... 34

Figure B - 4 Spectrum for Spot 4 Identified in Figure B - 3 for the OGCT Solids.................................... 34

Figure B - 5 Spectrum for Spot 5 Identified in Figure B - 3 for the OGCT Solids..................................... 35

Figure B - 6 Spectrum for Spot 6 Identified in Figure B - 3 for the OGCT Solids..................................... 35

Figure B - 7 CSEM Picture of the OGCT Solids (Magnification of 1000x) …........................................ 36

Figure B - 8 Spectrum for Spot 7 Identified in Figure B - 7 for the OGCT Solids................................... 36

Figure B - 9 CSEM Picture of the OGCT Solids (Magnification of 500x) …........................................ 37

Figure B - 10 Spectrum for Spot 8 Identified in Figure B - 9 for the OGCT Solids..................................37

Figure B - 11 Spectrum for Spot 9 Identified in Figure B - 9 for the OGCT Solids.................................. 38

Figure B - 12 Spectrum for Spot 10 Identified in Figure B - 9 for the OGCT Solids.................................38

Figure B - 13 Spectrum for Spot 11 Identified in Figure B - 9 for the OGCT Solids................................ 39

\section{LIST OF TABLES}

Table 1 - Results for the OGCT Sample and Comparison with a Previous OGCT Sample.......................10

Table 2 - Comparison of the Major Components of the Solids in the Current and Previous OGCT

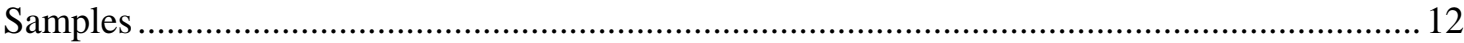

Table 3 - Comparison of the Elements Reported for the Supernate Sample of Scale Glass Melter

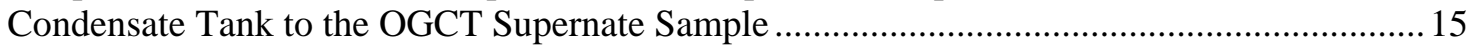

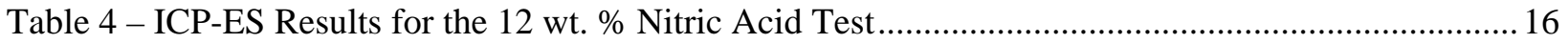

Table 5 - ICP-ES Results for the 50 wt. \% Nitric Acid Test .............................................................. 17

Table 6 - Comparison of the Total Grams Dissolved After 24 Hours for the 12 wt.\% and 50 wt.\% Nitric Acid Test Cases...

Table A-1 - Averages, Percent Relative Standard Deviations, Blanks, and Standards for the OGCT Data

Table A- 2 - Results of the Aqua-Regia Digestion of the OGCT Solids ............................

Table A- 3 - Results of the Sodium Peroxide Fusion Digestion of the OGCT Solids ...............................28

Table A- 4 - Concentrations of $\mathrm{Al}, \mathrm{Fe}, \mathrm{Mg}, \mathrm{Mn}, \mathrm{Na}, \mathrm{Ni}$, and Si in the Initial Supernate and Volume

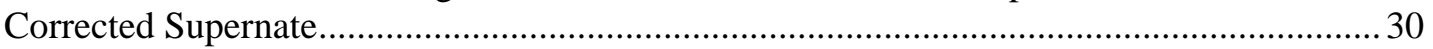

Table A- 5 - Supernate Data for the 12 wt.\% and 50 wt. \% Test Cases ................................................... 31 


\title{
LIST OF ACRONYMS
}

\author{
ADS - Analytical Development Section \\ CSEM - Contained Scanning Electron Microscopy \\ CXRD - Contained X-Ray Diffraction \\ DWPF - Defense Waste Processing Facility \\ HEME - High Efficiency Mist Eliminator \\ IC - Ion Chromatography \\ ICP-ES - Inductively Coupled Plasma Emission Spectrometer \\ ICP-MS - Inductively Coupled Plasma Mass Spectroscopy \\ ITS - Immobilization Technology Section \\ OGCT- Off Gas Condensate Tank \\ RCT- Recycle Collection Tank \\ SEM - Scanning Electron Microscopy \\ SGM - Scale Glass Melter \\ SGMCT - Scale Glass Melter Condensate Tank \\ SRNL - Savannah River National Laboratory \\ TAR - Technical Assistance Request \\ XRD - X-Ray Diffraction
}




\subsection{INTRODUCTION AND BACKGROUND}

The Off Gas Condensate Tank (OGCT) at the Defense Waste Processing Facility (DWPF) collects the condensate from the off-gas system of the melter. The condensate stream contains entrained solids that collect in the OGCT. Water from the OGCT is re-circulated to the Steam Atomized Scrubber and quencher and may provide a mechanism for re-introducing the particulates into the off-gas system. These particulates are thought to be responsible for plugging the downstream High Efficiency Mist Eliminator (HEME) filters. Therefore, the OGCT needs to be periodically cleaned to remove the build-up of entrained solids. Currently, the OGCT is cleaned by adding nominally $12 \mathrm{wt} \%$ nitric acid with agitation to slurry the solids from the tank. A Technical Assistance Request (TAR) was issued for Savannah River National Lab (SRNL) to characterize the OGCT solids and conduct tests to determine the optimum nitric acid concentration and residence time to allow more effective cleaning of the OGCT. ${ }^{3}$ This report summarizes the chemical and radionuclide results and the results from the nitric acid dissolution testing at $50 \%$ and $12 \%$ obtained for the OGCT sample.

\subsection{APPROACH}

\subsection{Characterization of the OGCT Samples}

Eight samples ( $125 \mathrm{~mL} /$ per sample) were taken from the OGCT at the DWPF. The samples were transported to SRNL for characterization. Upon receipt, the samples were placed into the Shielded Cells, then mixed, and poured into a calibrated 2-liter bottle. The total volume of the composite samples was $1100 \mathrm{~mL}$. The OGCT sample contained visible brown solids. The solids appeared to be made up of fine particulates and settled very slowly. However, when aliquots of the sample were removed from the sample bottle, mixed using a magnetic stir bar, a difference in the amount of solids was clearly seen between samples removed from the top of the solution versus samples obtained from the bottom of the sample bottle. These aliquots were placed back in the sample bottle and a mechanical mixer was used to provide homogenous slurry. This indicates the presence of heavier, fast settling particles in the OGCT sample in addition to fine particles. Samples of the OGCT Slurry, filtered supernate, and dissolutions of the OGCT solids were submitted for analyses to obtain the following data:

$-\mathrm{pH}$

- Weight percent total solids

- Weight percent dissolved solids in the supernate

- Calculation for the insoluble and the soluble solids

- Direct measurement of the insoluble solids by filtration for insoluble solids

- Density measurements for slurry and supernate

- Inductively Coupled Plasma Emission Spectroscopy (ICP-ES) results

- Inductively Coupled Plasma Mass Spectroscopy (ICP-MS) results

- Gamma Counting Data

- Ion Chromatography (IC) results for anions

- Particle Size

- Contained X-Ray Diffraction and Scanning Electron Microscope (CXRD/CSEM) analysis of the solids

A brief description of the analytical methods is provided in Section 2.2. 


\subsection{Brief Description of Analyses Performed for the OGCT}

$\mathrm{pH}$ Measurements

To perform the $\mathrm{pH}$ measurements, a portion of each sample was removed and checked with an in-cell $\mathrm{pH}$ probe. The probe is first standardized with buffer solutions at a $\mathrm{pH}$ of 10 and 7 . The probe is then checked with a $\mathrm{pH} 4$ buffer solution. Once the $\mathrm{pH}$ probe has been checked out, the $\mathrm{pH}$ measurement of the samples are completed. After the completion of the sample measurements, the $\mathrm{pH}$ probe is then checked again with the buffer solutions to determine if the $\mathrm{pH}$ probe drifted away from the initial standardization.

Weight Percent Solids Measurements

To perform the weight percent solids measurement for the sludge slurry, mixed samples of sludge slurry were pipetted out of the one-liter container and placed into labeled beakers. These beakers are weighed and then placed into a drying oven at $115^{\circ} \mathrm{C}$ overnight. Samples of a $\mathrm{NaCl}$ solution with a known weight percent total solids are also weighed and dried (in labeled beakers) along with the sludge slurry samples to check the accuracy and precision of the method. All of the samples are removed from the oven and allowed to cool for $\sim 5$ minutes before they are weighed. Once a constant weight is obtained, the measurement is considered complete.

To obtain the supernate for the weight percent solids measurement, a mixed sample of the combined sludge slurry is filtered through a $0.45 \mu$ Nalgene ${ }^{\circledR}$ filter resulting in a clear supernate. The same procedure used for the sludge slurry is followed for the supernate.

Calculation of Insoluble Solids and Soluble Solids for the Slurry Sample

Once the average for the total weight percent solids of the sludge slurry and the average weight percent dissolved solids in the supernate values are determined, the soluble and insoluble weight percent solids were calculated. These values are calculated by using the following equations ${ }^{4}$ :

Equation 1: $\mathrm{W}_{\mathrm{is}}=\left(\mathrm{W}_{\mathrm{ts}}-\mathrm{W}_{\mathrm{ds}}\right) /\left(1-\mathrm{W}_{\mathrm{ds}}\right)$

Equation 2: $\mathrm{W}_{\mathrm{ss}}=\mathrm{W}_{\mathrm{ts}}-\mathrm{W}_{\text {is }}$

$\mathrm{W}_{\mathrm{ds}}$ - Weight fraction of dissolved solids (weight of dissolved solids/weight of supernate)

$\mathrm{W}_{\mathrm{ts}}$ - Weight fraction of total solids (weight of total solids/weight of sludge slurry)

$\mathrm{W}_{\mathrm{is}}$ - Weight fraction of insoluble solids (weight of insoluble solids/weight of sludge slurry)

$\mathrm{W}_{\mathrm{ss}}$ - Weight fraction of soluble solids (weight dissolved solids/weight of sludge slurry)

\section{Direct Measurement of the Weight Percent Insoluble Solids}

The direct measurement of the weight percent insoluble solids is accomplished by filtering a known weight of the slurry sample through a $0.45 \mu$ Nalgene ${ }^{\circledR}$ filter. The solids obtained from the slurry are allowed to partially dry on the filter to aid in the removal of the solids. The solids are placed in a weighed beaker and dried to constant weight in a drying oven at $100^{\circ} \mathrm{C}$. Since not all of the interstitial supernate is removed by filtration the result can be biased high when the supernate has a high concentration of dissolved solids and an alternate procedure must be used. However, the current OGCT sample contains very little dissolved solids.

Density Determinations for the Sludge Slurry and Supernate

Density measurements for the sludge slurry and supernate are completed remotely in the Shielded Cells Facility by using heat sealed pipette tips. The pipette tips are first sealed and then calibrated with water to obtain the volume. After determining the volume, density measurements are completed for the sludge slurry and supernate. The sealed pipette tip is first weighed and then a mixed sample of sludge slurry is 
pipetted into the sealed pipette tip. The sealed pipette tip containing the sludge slurry sample is weighed and a density calculated. The same protocol is used for the supernate samples. The supernate sample is obtained by filtering a portion of the sludge slurry through a $0.45 \mu$ Nalgene ${ }^{\circledR}$ filter.

\section{ICP-ES, ICP-MS, and Gamma Scan Analysis}

The ICP-ES method provides the data for the non-radioactive analytes plus total U. The ICP-MS method provides the data for fission product and actinide concentrations of the samples. The gamma scan provides the concentrations of the major gamma emitters present in the samples, such as Co-60, Eu-154, etc. Both the supernate and solids from the OGCT sample were analyzed by ICP-ES. Only the solids received analysis by ICP-MS and gamma scan.

Supernate sample were obtained by filtering a portion of the slurry sample through a $0.45 \mu$ Nalgene ${ }^{\circledR}$ filter. The supernate was submitted for ICP-ES analysis without any dilution.

Solids from the sample were dissolved per the dissolution techniques described below. The solids were obtained by filtering the sample through a $0.45 \mu$ Nalgene ${ }^{\circledR}$ filter. After drying the solids, three portions were dissolved by the Aqua Regia and Peroxide Fusion methods along with appropriate standards and blanks to check the dissolutions and the analytical methods. After performing the dissolution methods on the solids, a portion of the dissolved samples were removed from the Shielded Cells Facility. These dissolved samples were sent to Analytical Development Section (ADS) Sample Receiving for analyses to be performed by ADS.

Ion Chromatography (IC) Analysis for Anions

Three aliquots of the filtered supernate were analyzed ion chromatography. No dilution of the supernate samples was necessary due to the low activity present in the samples

\section{Particle Size Analysis}

Samples of the damp OGCT solids, obtained from filtration of the slurry, were sent for particle size analysis by Contained Scanning Electron Microscopy.

Contained X-Ray Diffraction and Scanning Electron Microscope (XRD/SEM) Analysis

Samples of the OGCT solids, obtained from filtration of the slurry, were dried and sent for analysis by $\mathrm{XRD} / \mathrm{SEM}$.

\subsection{Demonstration of the OGCT Tank Cleaning Method with Different Concentrations of Nitric Acid Solutions}

Currently, DWPF cleans the OGCT by pumping the contents down to approximately 1200 gallons and adding $~ 850$ gallons of $50 \mathrm{wt}$. \% nitric acid followed by 1450 gallons of process water. DWPF agitates the nitric acid solution for 8 to 12 hours prior to pumping the OGCT contents to the Recycle Collection Tank. In order to optimize the cleaning protocol for the OGCT, the chemical additions and residence time for the tank were considered for the SRNL testing.

DWPF can add process water, a $50 \mathrm{wt}$ \% sodium hydroxide solution, or a $50 \mathrm{wt}$ \% nitric acid solution to the OGCT. The $50 \mathrm{wt}$ \% sodium hydroxide solution was not considered for the SRNL testing, because the contents of the OGCT are already acidic, and the addition of sodium hydroxide may precipitate any soluble solids in the supernate (although the concentration of these soluble solids are very low).

Two concentrations of nitric acid solutions, $12 \mathrm{wt}$ \% and $50 \mathrm{wt}$ \%, were selected for the SRNL testing. The $12 \mathrm{wt}$. \% nitric acid solution was selected to determine how effective the cleaning process is at a lower concentration of nitric acid, and to determine if more solids would dissolve as the residence time 
was extended. The $50 \mathrm{wt}$. \% nitric acid test was selected to determine if a more concentrated acid would dissolve more of the solids faster than the $12 \mathrm{wt}$ \% nitric acid solution. For both tests, the same volume ratio of OGCT solution to nitric acid solution was maintained. A volume ratio of 0.34 was selected based on previous information obtained from DWPF. The actual volumes used for each test were $120 \mathrm{~mL}$ of OGCT solution and $350 \mathrm{~mL}$ of nitric acid solution (at concentrations of $12 \mathrm{wt}$ \% and $50 \mathrm{wt}$ \%). Both tests were agitated for 24 hours and samples were pulled and filtered at time zero, 2 hours, 8 hours, and 24 hours after the addition of the nitric acid solution to the OGCT solution. These filtered solutions were then submitted to ADS and analyzed by ICP-ES. This was completed in order to determine dissolution rates and the total amount of soluble solids dissolved after 24 hours. It should be noted that the actual concentration of the OGCT solution after the nitric acid additions were not $12 \mathrm{wt}$. \% and $50 \mathrm{wt}$. \%, but lower. Accounting for the nitrate and dilution of the starting OGCT solution, the actual concentrations of the solutions were calculated at $9.2 \mathrm{wt}$. \% and $39.6 \mathrm{wt}$ \% nitric acid for the $12 \mathrm{wt}$. \% and 50wt. \% test cases, respectively. These nitric acid concentrations bound the $14.8 \mathrm{wt}$ \% calculated for the DWPF OGCT.

\subsection{RESULTS FOR THE OGCT SAMPLES}

The following sections present the results for the characterization task and the dissolution testing for the OGCT sample.

\subsection{Summary of Analytical Data Obtained for the OGCT Samples}

The analyses described in Sections 2.1 and 2.2 were completed for the OGCT samples. Table 1 provides a summary of the data collected. The results of the analysis of a previous OGCT sample are included in Table 1 for comparison. ${ }^{1}$ Unless otherwise denoted in the Table 1 , the values presented are the average of three values. However, the results for the analysis of the dried solids (ICP-ES, ICP-MS, and Gamma Counting) are generally the average of six values, three values from each of two dissolution methods. For some elements, one of the dissolution methods may not produce reliable results and the average excludes those results. Values were also excluded when the blanks and standards showed values of similar magnitude indicating contamination of the samples for that analyte. All of the data including blanks and standards is included in the tables Table A-1 through Table A- 3 of APPENDIX A.

Table 1 - Results for the OGCT Sample and Comparison with a Previous OGCT Sample

\begin{tabular}{|c|c|c|c|}
\hline Category & Analyte & OGCT Results & Previous OGCT Results \\
\hline \multirow{2}{*}{ Wt.\% Solids and Density } & $\begin{array}{c}\text { Wt.\% Dissolved Solids of } \\
\text { Supernate }\end{array}$ & $0^{*}$ & $0.44^{\mathrm{b}}$ \\
\hline & Wt. \% Total Solids of Slurry & $0.37^{\mathrm{a}}$ & 0.44 \\
\hline & Wt.\% Insoluble Solids & 0.37 & 0 \\
\hline & Wt.\% Soluble Solids & 0 & N.M. \\
\hline & $\begin{array}{c}\text { Wt.\% Insoluble Solids } \\
\text { Direct Measurement }\end{array}$ & $0.41^{\mathrm{a}}$ & 1.02 \\
\hline & Slurry Density, g/mL & 1.00 & 0.99 \\
\hline Supernate Density, g/mL & 1.00 & 2.3 \\
\hline ICP-ES (mg/L of filtered & $\mathrm{pH}$ & 2.5 & N.M. \\
\hline supernate) & $\mathrm{Al}$ & $2.61 \mathrm{E}+01^{\mathrm{c}}$ & N.M. \\
\hline & $\mathrm{Ca}$ & $5.98 \mathrm{E}+00^{\mathrm{c}}$ & N.M. \\
\hline & $\mathrm{Fe}$ & $1.89 \mathrm{E}+00^{\mathrm{c}}$ & N.M. \\
\hline & $\mathrm{Mg}$ & $3.85 \mathrm{E}+00^{\mathrm{c}}$ & N.M. \\
\hline & $\mathrm{Mn}$ & $8.10 \mathrm{E}+00^{\mathrm{c}}$ & N.M. \\
\hline & $\mathrm{Na}$ & $4.16 \mathrm{E}+01^{\mathrm{c}}$ & N.M. \\
\hline
\end{tabular}


WSRC-TR-2005-00141

Revision 0

\begin{tabular}{|c|c|c|c|}
\hline Category & Analyte & OGCT Results & Previous OGCT Results \\
\hline & $\mathrm{U}$ & $1.63 \mathrm{E}+01^{\mathrm{c}}$ & N.M. \\
\hline \multirow{8}{*}{ Anions (mg/L of supernate) } & Chloride & $2.0 \mathrm{E} 00^{\mathrm{C}}$ & $5 \mathrm{E} 00^{\mathrm{d}}$ \\
\hline & Formate & $2.0 \mathrm{E} 00^{\mathrm{C}}$ & $<1.4 \mathrm{E} 01^{\mathrm{d}}$ \\
\hline & Fluoride & $5.0 \mathrm{E} 00^{\mathrm{c}}$ & $1.9 \mathrm{E} 01^{\mathrm{d}}$ \\
\hline & Nitrate & $5.15 \mathrm{E} 02^{\mathrm{C}}$ & $1.59 \mathrm{E} 03^{\mathrm{d}}$ \\
\hline & Nitrite & $<1.0 \mathrm{E} 01^{\mathrm{C}}$ & $<1.4 \mathrm{E} 01^{\mathrm{d}}$ \\
\hline & Oxalate & $<1.0 \mathrm{E} 01^{\mathrm{c}}$ & $<1.4 \mathrm{E} 01^{\mathrm{d}}$ \\
\hline & Phosphate & $<1.0 \mathrm{E} 01^{\mathrm{C}}$ & $<1.4 \mathrm{E} 01^{\mathrm{d}}$ \\
\hline & Sulfate & $2.87 \mathrm{E} 01^{\mathrm{C}}$ & $6.1 \mathrm{E} 01^{\mathrm{d}}$ \\
\hline \multirow{31}{*}{ ICP-ES (wt.\% dried solids) ${ }^{\mathrm{e}}$} & $\mathrm{Ag}$ & $2.48 \mathrm{E}-02$ & $1.34 \mathrm{E}-02$ \\
\hline & $\mathrm{Al}$ & $2.66 \mathrm{E} 00$ & $2.36 \mathrm{E} 00$ \\
\hline & $\mathrm{B}$ & $1.70 \mathrm{E}-01$ & 5.03E-01 \\
\hline & $\mathrm{Ba}$ & 4.77E-02 & 3.08E-02 \\
\hline & $\mathrm{Be}$ & $5.36 \mathrm{E}-04$ & $2.85 \mathrm{E}-04$ \\
\hline & $\mathrm{Ca}$ & $2.04 \mathrm{E}-01$ & 5.13E-01 \\
\hline & $\mathrm{Cd}$ & 4.40E-01 & $3.24 \mathrm{E}-01$ \\
\hline & $\mathrm{Ce}$ & 6.37E-02 & 4.84E-02 \\
\hline & $\mathrm{Cr}$ & 8.99E-02 & 8.29E-02 \\
\hline & $\mathrm{Cu}$ & $4.02 \mathrm{E}-02$ & $2.74 \mathrm{E}-02$ \\
\hline & $\mathrm{Fe}$ & 3.63E01 & $2.26 \mathrm{E} 01$ \\
\hline & Gd & $2.91 \mathrm{E}-02$ & $2.02 \mathrm{E}-02$ \\
\hline & $\mathrm{La}$ & $2.00 \mathrm{E}-02$ & $1.75 \mathrm{E}-02$ \\
\hline & $\mathrm{Li}$ & 2.63E-01 & $2.21 \mathrm{E}-01$ \\
\hline & $\mathrm{Mg}$ & $1.93 \mathrm{E} 00$ & $1.27 \mathrm{E} 00$ \\
\hline & $\mathrm{Mn}$ & $4.85 \mathrm{E} 00$ & $2.69 \mathrm{E} 00$ \\
\hline & Mo & $1.41 \mathrm{E}-01$ & $7.76 \mathrm{E}-02$ \\
\hline & $\mathrm{Na}$ & 4.73E-01 & $3.71 \mathrm{E} 00$ \\
\hline & $\mathrm{Ni}$ & $1.94 \mathrm{E} 00$ & $1.18 \mathrm{E} 00$ \\
\hline & $\mathrm{P}$ & $4.51 \mathrm{E}-01$ & $3.35 \mathrm{E}-01$ \\
\hline & $\mathrm{Pb}$ & $<9.1 \mathrm{E}-02$ & $4.16 \mathrm{E}-02$ \\
\hline & $\mathrm{S}$ & 2.32E-01 & 4.73E-01 \\
\hline & $\mathrm{Sb}$ & $1.52 \mathrm{E}-01$ & $7.51 \mathrm{E}-02$ \\
\hline & $\mathrm{Si}$ & $7.32 \mathrm{E} 00$ & $3.74 \mathrm{E} 00^{b}$ \\
\hline & Sn & 1.77E-01 & 1.19E-01 \\
\hline & $\mathrm{Sr}$ & 5.24E-02 & 1.33E-01 \\
\hline & $\mathrm{Ti}$ & $3.49 \mathrm{E}-02$ & $1.55 \mathrm{E}-02$ \\
\hline & $\mathrm{U}$ & 2.24E-01 & $1.52 \mathrm{E} 00$ \\
\hline & $\mathrm{V}$ & $5.54 \mathrm{E}-03$ & $<3.0 \mathrm{E}-02$ \\
\hline & $\mathrm{Zn}$ & $6.10 \mathrm{E}-02$ & $3.82 \mathrm{E}-02$ \\
\hline & $\mathrm{Zr}$ & $1.26 \mathrm{E}-01$ & $9.48 \mathrm{E}-02$ \\
\hline \multirow[t]{4}{*}{$\begin{array}{c}\text { ICP-MS Results (wt.\% dried } \\
\text { solids) }\end{array}$} & Pu-239 & 3.00E-02 & $1.46 \mathrm{E}-02$ \\
\hline & Pu-240 & 3.07E-03 & $1.36 \mathrm{E}-03$ \\
\hline & Pu-242 & 1.61E-04 & 6.92E-05 \\
\hline & U-total $^{\mathrm{f}}$ & $1.75 \mathrm{E}-01$ & $1.32 \mathrm{E} 00$ \\
\hline \multirow[t]{5}{*}{$\begin{array}{c}\text { Gamma Counting }(\mu \mathrm{Ci} / \mathrm{g} \text { of } \\
\text { dried solids) }\end{array}$} & Cs-137 & 7.00E01 & $1.62 \mathrm{E} 02$ \\
\hline & Eu-154 & $3.05 \mathrm{E} 00$ & $3.06 \mathrm{E} 00$ \\
\hline & Co-60 & $3.15 \mathrm{E} 00$ & $1.95 \mathrm{E} 00$ \\
\hline & Am-241 & $1.54 \mathrm{E} 01$ & $1.06 \mathrm{E} 01$ \\
\hline & Total Gamma $^{\mathrm{g}}$ & $9.16 \mathrm{E} 01$ & $1.84 \mathrm{E} 02$ \\
\hline
\end{tabular}

* Three measurements were completed. The results indicate that there were no soluble solids per a three place balance.

${ }^{\text {a }}$ Average of two values.

${ }^{\mathrm{b}}$ Due to the low amount of solids present in the OGCT sample, one large sample was dried for weight percent solids.

${ }^{\mathrm{c}}$ To convert the data from a supernate basis to a slurry basis multiply the value by $1.00 \mathrm{~mL}$ of supernate / $\mathrm{mL}$ of slurry.

${ }^{\mathrm{d}}$ To convert the data from a supernate basis to a slurry basis multiply the value by $1.03 \mathrm{~mL}$ of supernate / $\mathrm{mL}$ of slurry. It should be noted that this ratio

should not exceed 1.00. If it exceeds 1.00 , it is probably due to analytical error associated with the measurements completed for the sample.

${ }^{\mathrm{e}}$ The data for the solids of the current sample are on a dried insoluble solids basis. The previous sample results are on a dried total solids basis.

${ }^{\mathrm{f}}$ More than one isotope was used to calculate the weight percent.

${ }^{g}$ To obtain the total gamma, the gamma emitters were added together.

N.M. - Not Measured 
Based on the OGCT data presented in Table 1, Fe appears to be the dominant component in the solids followed by Si, Mn, Al, Ni, and Mg. No measurable soluble solids were detected for the supernate. The concentration of nitrate present in the supernate correlates to $\sim 0.008 \mathrm{~N}$ nitric acid solution which is in agreement with the $\mathrm{pH}$ of the sample. Some differences between the current sample and the previous sample can be seen in the results of the solids analysis. The uranium concentration in the solids is almost an order of magnitude lower in current sample than the previous sample. The iron and silicon in the current sample are significantly higher than the in the previous sample.

In general, the values of the solids analysis for the current sample are slightly higher than the previous sample. Some of this difference can be attributed to the sample preparation. The previous sample dried a large portion of the slurry and represents analysis of the total dried solids of the sample. In the current sample the insoluble solids were filtered from the slurry and dried. The major components of the solids for the current sample and the previous sample normalized to iron are shown in Table 2. The ratios are similar indicating the samples contain primarily the same composition of entrained solids.

Table 2 - Comparison of the Major Components of the Solids in the Current and Previous OGCT Samples

\begin{tabular}{|c|c|c|}
\hline Analyte & $\begin{array}{c}\text { Major } \\
\text { Components } \\
\text { Normalized to Fe } \\
\text { (Current Sample) }\end{array}$ & $\begin{array}{c}\text { Major } \\
\text { Components } \\
\text { Normalized to Fe } \\
\text { (Previous Sample) }\end{array}$ \\
\hline $\mathrm{Al}$ & 0.07 & 0.10 \\
\hline $\mathrm{Fe}$ & 1.00 & 1.00 \\
\hline $\mathrm{Mg}$ & 0.05 & 0.06 \\
\hline $\mathrm{Mn}$ & 0.13 & 0.12 \\
\hline $\mathrm{Ni}$ & 0.05 & 0.05 \\
\hline $\mathrm{Si}$ & 0.20 & 0.17 \\
\hline
\end{tabular}

\subsection{Contained X-Ray Diffraction (CXRD) and Contained Scanning Electron Microscopy (CSEM) Results for Filtered Samples of the OGCT Solids}

Three samples of filtered OGCT solids were submitted to ADS for CXRD and CSEM analyses. The CXRD results indicated that hematite and magnetite (oxides of $\mathrm{Fe}$ ) are present in the OGCT solids, but did not identify any other compounds that may be present. Figure 1 is an example of the spectra collected from one of the three samples. 


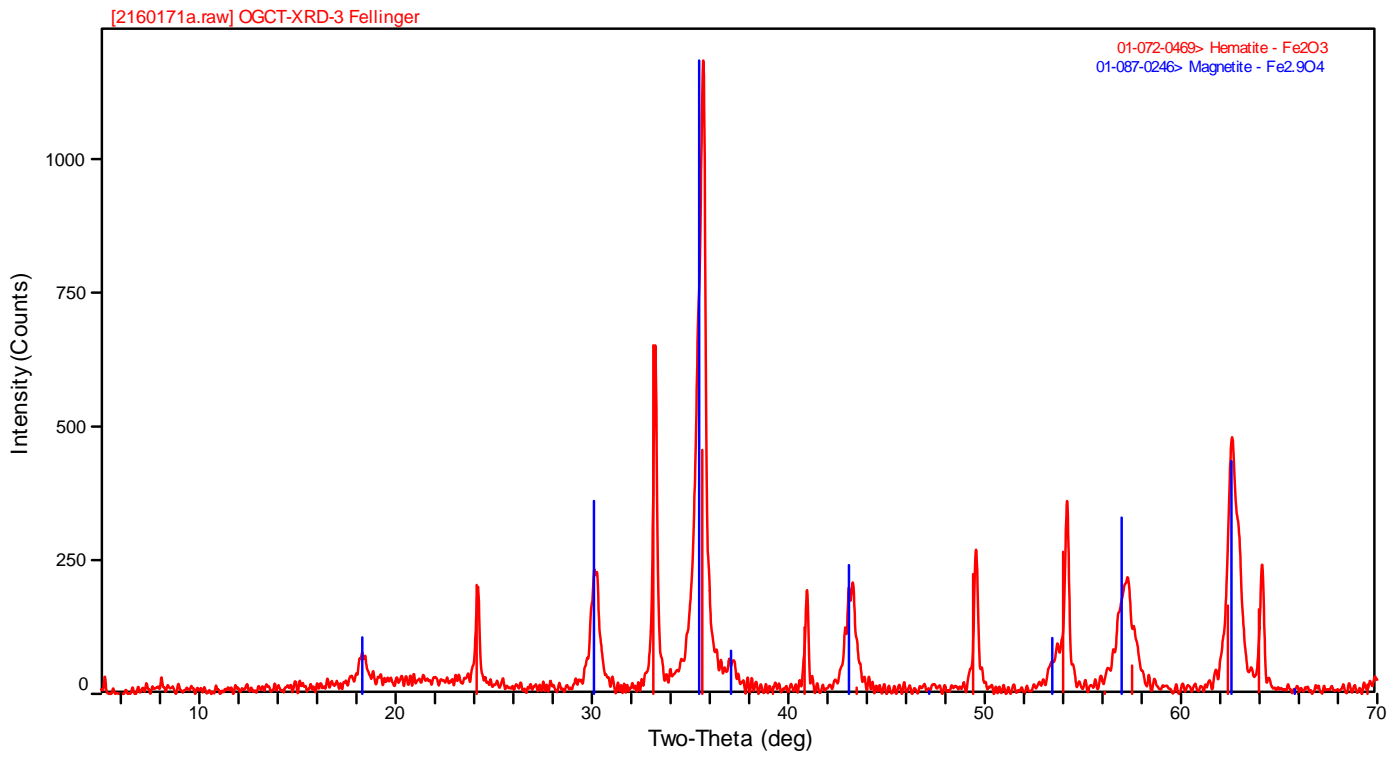

Figure 1 - Spectra from CXRD Analyses of the OGCT Sample

For the CSEM analysis, several of the major and minor elements present in the OGCT solids were identified. Figure 2 is a picture of the OGCT solids taken at magnification of 50x.

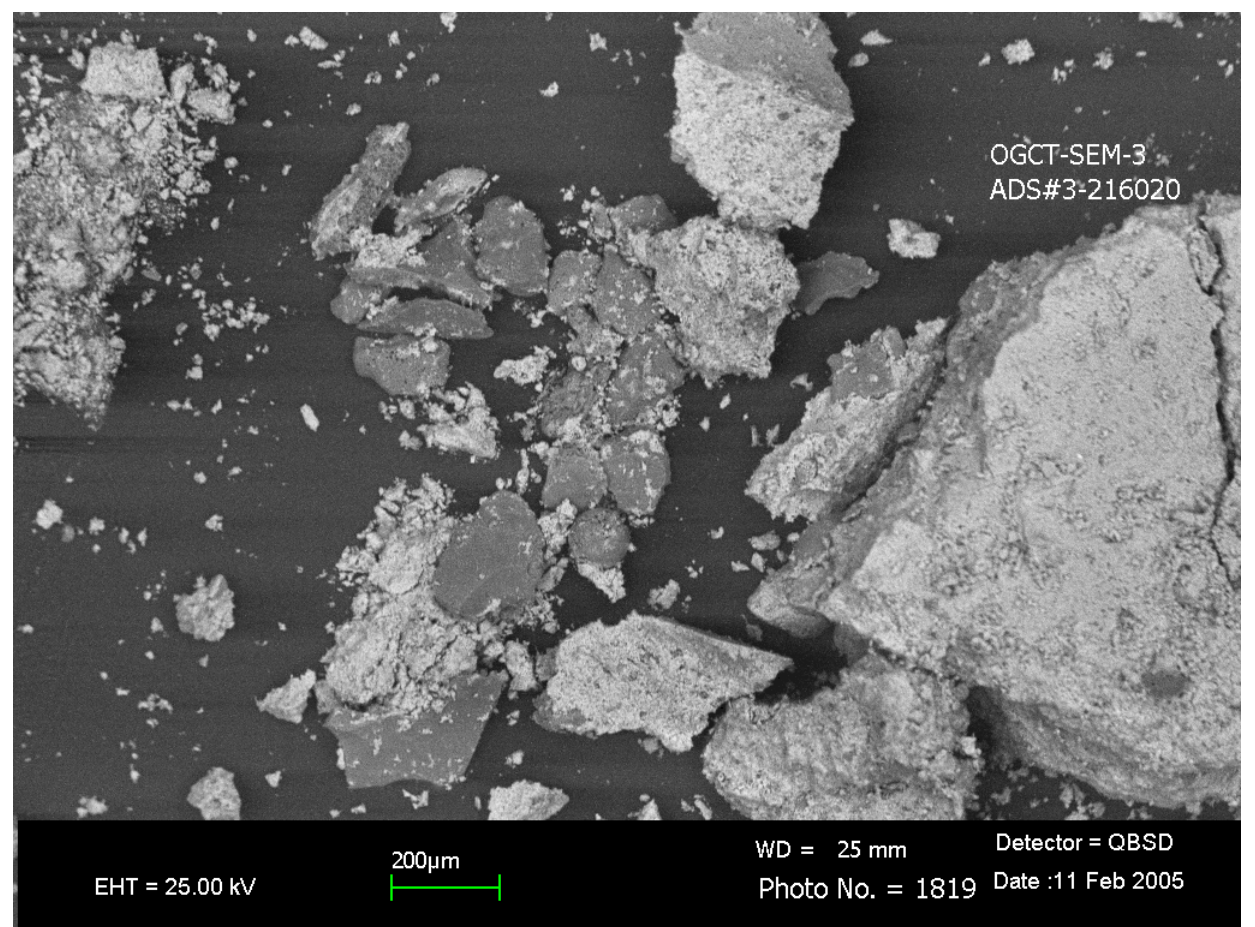

Figure 2 - CSEM Picture of the OGCT Solids (Magnification of 50x) 
From Figure 2, it appears that some of the particles are larger than $200 \mu \mathrm{m}$ and others are very small. It also appears that the particles are different colors which may indicate different compositions. Figure 3 is a 240x magnification of some of the different colored particles seen in Figure 2. The spectra for the spots identified in Figure 3 are presented in Figure 4 and Figure 5. See APPENDIX B for other CSEM pictures and spectra.

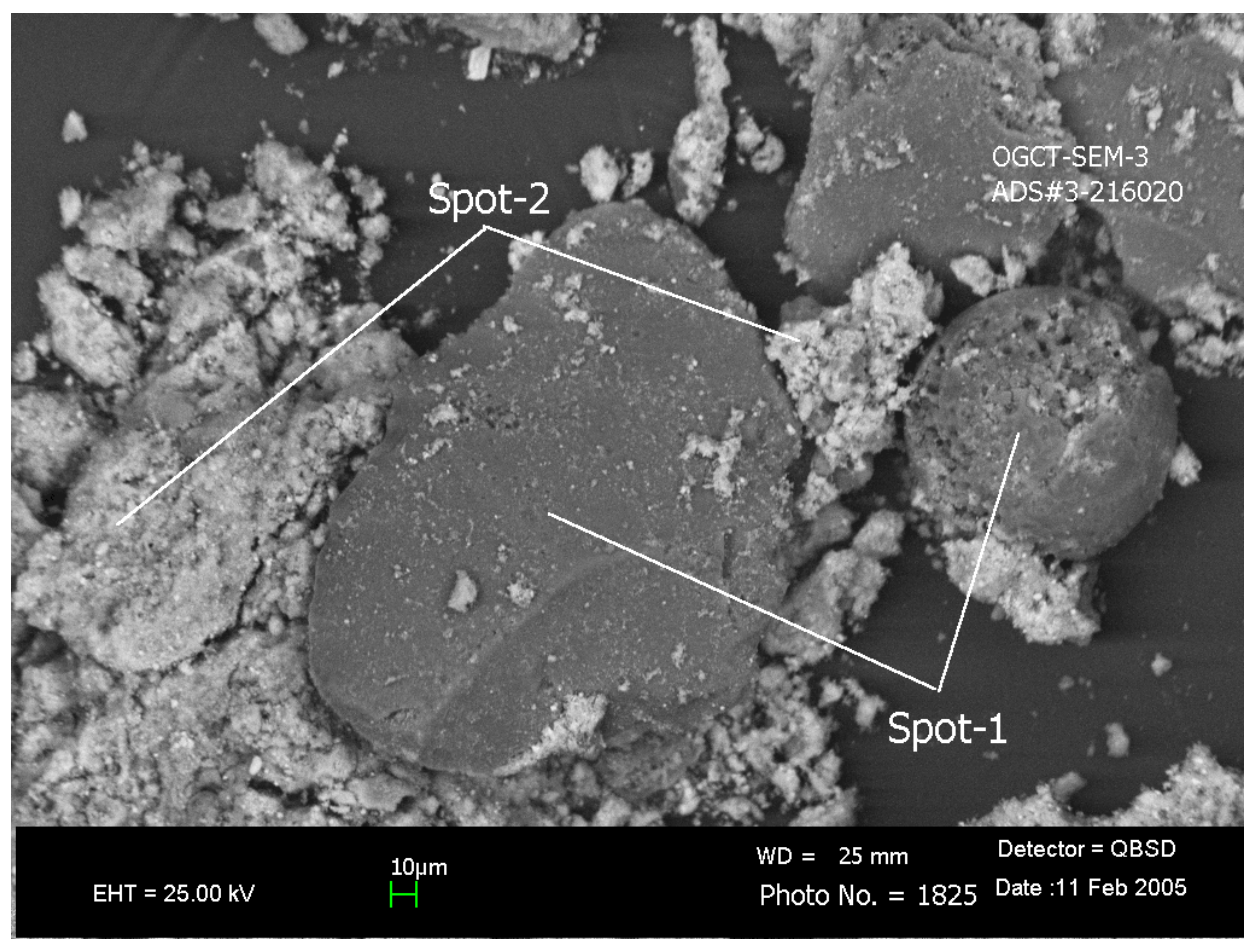

Figure 3 - CSEM Picture of the OGCT Solids (Magnification of 240x)

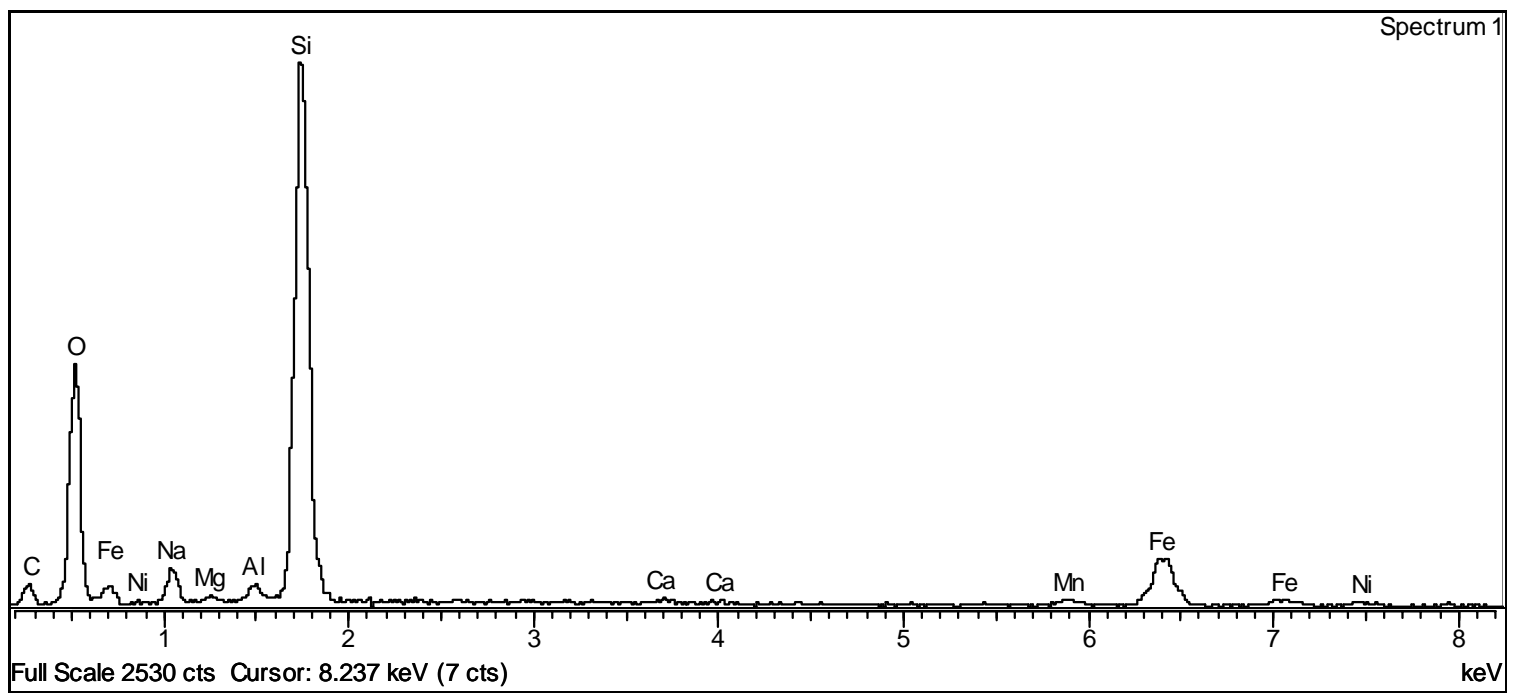

Figure 4 - Spectrum for Spot 1 Identified in Figure 3 for the OGCT Solids 


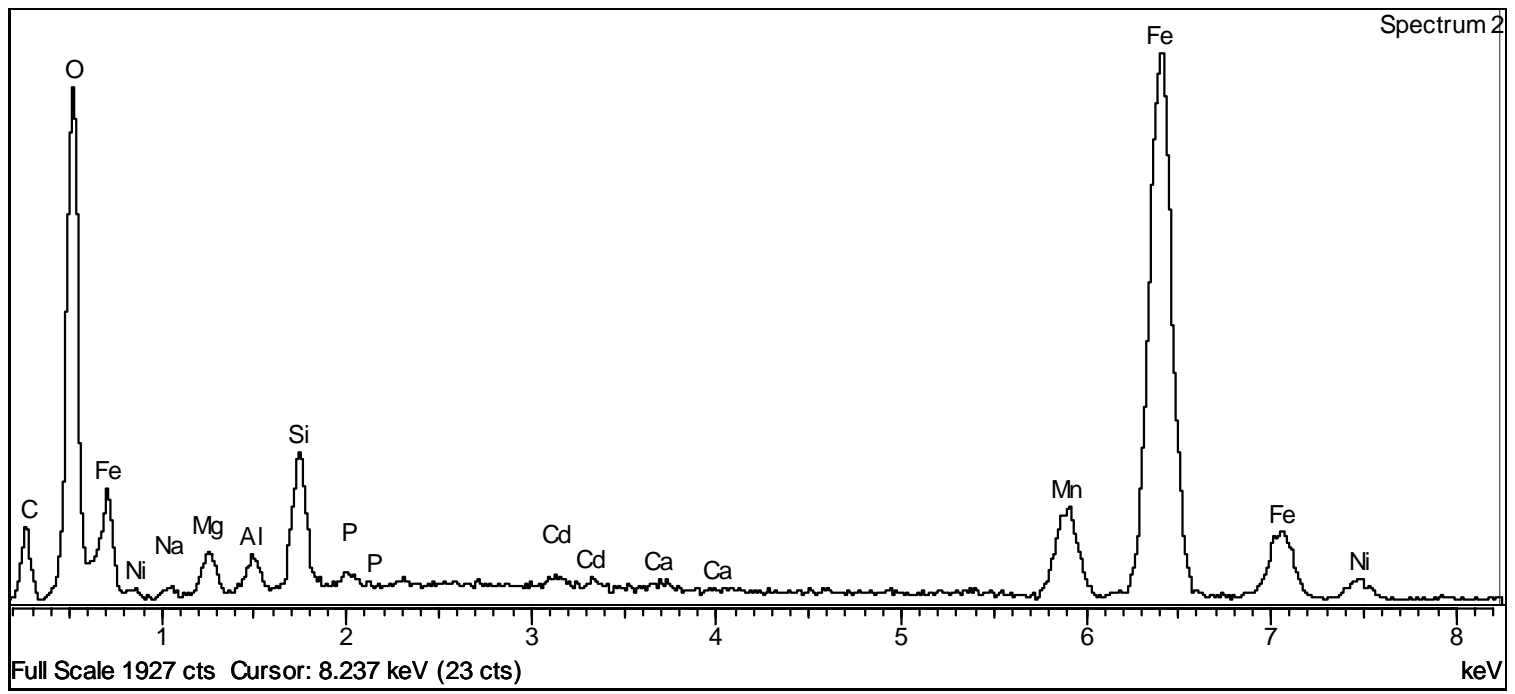

Figure 5 - Spectrum for Spot 2 Identified in Figure 3 for the OGCT Solids

It appears that Spot 1 in Figure 3 is rich in $\mathrm{Si}$, but also has a minor contribution from the sludge components (Fe, Na, Ni, Mn, $\mathrm{Al}, \mathrm{Mg}$ and $\mathrm{Ca}$ ). Spot 2 appears to be rich in Fe and other sludge components with a minor contribution from Si. The elements reported from the CSEM analyses are consistent with the elements previously reported by C.M. Jantzen for a nonradioactive sample of the Condensate Tank for the Scale Glass Melter (SGM) ${ }^{2}$. C.M. Jantzen submitted a solid sample and supernate sample for analysis. The solids were analyzed by Scanning Electron Microscopy (SEM) and XRay Diffraction (XRD). The supernate was analyzed by ICP-ES. The major elements reported for the supernate fraction consisted of $\mathrm{Na}, \mathrm{B}, \mathrm{Ca}, \mathrm{K}, \mathrm{Li}, \mathrm{Mg}, \mathrm{P}$, and $\mathrm{Si}$. These elements were also found in the supernate of the OGCT, but the concentrations were not the same. Table 3 is a comparison of the elements reported for the supernate of SGM Condensate Tank to the supernate of the OGCT.

Table 3 - Comparison of the Elements Reported for the Supernate Sample of Scale Glass Melter Condensate Tank to the OGCT Supernate Sample

\begin{tabular}{|c|c|c|}
\hline Element & $\begin{array}{c}\text { SGM Condensate Tank } \\
\text { Sample } \\
\mathbf{m g} / \mathbf{L}^{\mathbf{a}}\end{array}$ & $\begin{array}{c}\text { OGCT Sample } \\
\mathbf{m g} / \mathbf{L}^{\mathbf{b}}\end{array}$ \\
\hline $\mathbf{B}$ & 35 & 3.51 \\
\hline $\mathbf{C a}$ & 7 & 5.98 \\
\hline $\mathbf{K}$ & 5.87 & $<1$ \\
\hline $\mathbf{L i}$ & 2.5 & 0.90 \\
\hline $\mathbf{M g}$ & 1.7 & 3.85 \\
\hline $\mathbf{N a}$ & 478 & 41.6 \\
\hline $\mathbf{P}$ & 3 & 0.46 \\
\hline $\mathbf{S i}$ & 4 & 11.8 \\
\hline
\end{tabular}

${ }^{\mathrm{a}}$ No information about the number of samples analyzed was available

${ }^{\mathrm{b}}$ Average of three samples

From the data in Table 3, it was noted that the concentrations reported for some of the elements are off by an order of magnitude. This is expected, due to the different compositions of the melter feed being fed to the melter. The XRD results for the C.M. Jantzen sample indicated that the solid fraction of the sample contained deposits that were rich in $\mathrm{Si}$, and spinel forming elements ( $\mathrm{Al}, \mathrm{Fe}, \mathrm{Mn}$, and $\mathrm{Ni}$ ). The CXRD 
results for the OGCT sample indicated that two forms of Fe oxides were present in the sample, but did not identify any $\mathrm{SiO}_{2}$ or any of the other spinel forming components such as $\mathrm{Al}, \mathrm{Mn}$, or Ni. The SEM results for the C.M. Jantzen sample confirmed the results of the XRD and found deposits that were rich in Si as well as spinel forming elements (Al, Fe, Mn, and Ni). C.M. Jantzen also concluded that deposits containing entrained spinel and frit were being carried from the melter plenum to the condensate tank. The elements reported for the OGCT sample could also be due to spinels and frit being carried from the melter plenum as observed in the C.M. Jantzen sample.

\subsection{ICP-ES Results of the OGCT Tank Cleaning Method Tests}

This section presents the results collected from the nitric acid dissolution testing described in Section 2.3. Table 4 provides a summary of the ICP-ES supernate data collected for the $12 \mathrm{wt}$ \% nitric acid test. Table 5 provides a summary of the ICP-ES supernate data collected for the $50 \mathrm{wt}$ \% nitric acid test. Since these tests were conducted to determine if the solids were dissolving over time, seven elements (Al, $\mathrm{Fe}, \mathrm{Mg}, \mathrm{Mn}, \mathrm{Na}, \mathrm{Ni}$, and $\mathrm{Si}$ ) having the highest concentration in the OGCT solids were selected from Table 1. The data sets for both tables include the concentrations of the supernate samples taken prior to the addition of the nitric acid solutions (corrected for volume $470 \mathrm{~mL} / 120 \mathrm{~mL}$, See APPENDIX A, Table A- 4), at time zero (addition of nitric acid), 2 hours, 8 hours, and 24 hours for each test, respectively. Unless otherwise denoted, the concentrations presented in Table 4 and Table 5 is the average of two values. APPENDIX A, Table A- 5 contains the averages, standard deviations, and percent relative standard deviations.

Table 4 - ICP-ES Results for the 12 wt. \% Nitric Acid Test

\begin{tabular}{|c|c|c|c|c|c|}
\hline Element & $\begin{array}{l}\text { OGCT Conc. Prior to } \\
\text { Addition of } \mathrm{HNO}_{3} \\
\qquad(\mathrm{mg} / \mathrm{L})^{\mathrm{a}}\end{array}$ & $\begin{array}{c}\text { Time Zero (After } \\
\mathrm{HNO}_{3} \text { is Added) } \\
(\mathrm{mg} / \mathrm{L})^{\mathrm{b}}\end{array}$ & $\begin{array}{l}\text { Time }-2 \\
\text { Hours } \\
(\mathrm{mg} / \mathrm{L})^{\mathrm{b}}\end{array}$ & $\begin{array}{l}\text { Time }-8 \\
\text { Hours } \\
(\mathrm{mg} / \mathrm{L})^{\mathrm{b}}\end{array}$ & $\begin{array}{c}\text { Time }-24 \\
\text { Hours } \\
(\mathrm{mg} / \mathrm{L})^{\mathrm{b}}\end{array}$ \\
\hline $\mathrm{Al}$ & 6.66 & 8.93 & 11.00 & 13.90 & 18.30 \\
\hline $\mathrm{Fe}$ & 0.48 & 6.13 & 46.60 & 85.50 & 129.00 \\
\hline $\mathrm{Mg}$ & 0.98 & 2.26 & 5.51 & 11.70 & 15.40 \\
\hline $\mathrm{Mn}$ & 2.07 & 2.69 & 11.00 & 18.90 & 24.60 \\
\hline $\mathrm{Na}$ & 10.63 & 13.40 & 13.50 & 15.20 & 14.40 \\
\hline $\mathrm{Ni}$ & 0.22 & 0.28 & 2.35 & 5.00 & 7.94 \\
\hline $\mathrm{Si}$ & 3.02 & 3.96 & 5.04 & 6.32 & 8.00 \\
\hline
\end{tabular}

${ }^{\text {a }}$ Average of three results. Data has been corrected for volume (i.e. divided ICP-ES supernate data by $470 \mathrm{~mL} / 120 \mathrm{~mL}$ to obtain concentration in $470 \mathrm{~mL}$ ).

${ }^{\mathrm{b}}$ Average of two results 
Table 5 - ICP-ES Results for the 50 wt. \% Nitric Acid Test

\begin{tabular}{|c|c|c|c|c|c|}
\hline Element & $\begin{array}{c}\text { OGCT Conc. Prior to } \\
{\text { Addition of } \mathrm{HNO}_{3}}^{(\mathrm{mg} / \mathrm{L})^{\mathrm{a}}}\end{array}$ & $\begin{array}{c}\text { Time Zero (After } \\
\mathrm{HNO}_{3} \text { is Added) } \\
(\mathrm{mg} / \mathrm{L})^{\mathrm{b}}\end{array}$ & $\begin{array}{c}\text { Time }-2 \\
\text { Hours } \\
(\mathrm{mg} / \mathrm{L})^{\mathrm{b}}\end{array}$ & $\begin{array}{c}\text { Time }-8 \\
\text { Hours } \\
(\mathrm{mg} / \mathrm{L})^{\mathrm{b}}\end{array}$ & $\begin{array}{c}\text { Time }-24 \\
\text { Hours } \\
(\mathrm{mg} / \mathrm{L})^{\mathrm{b}}\end{array}$ \\
\hline $\mathrm{Al}$ & 6.66 & 9.23 & 13.90 & 17.90 & 22.90 \\
\hline $\mathrm{Fe}$ & 0.48 & 34.00 & 112.00 & 169.00 & 226.00 \\
\hline $\mathrm{Mg}$ & 0.98 & 4.00 & 13.30 & 19.80 & 24.40 \\
\hline $\mathrm{Mn}$ & 2.07 & 7.93 & 27.50 & 39.70 & 49.10 \\
\hline $\mathrm{Na}$ & 10.63 & 13.50 & 14.00 & 14.50 & 17.00 \\
\hline $\mathrm{Ni}$ & 0.22 & 1.46 & 6.83 & 10.50 & 13.90 \\
\hline $\mathrm{Si}$ & 3.02 & 6.07 & 13.70 & 17.50 & 17.40 \\
\hline
\end{tabular}

${ }^{\mathrm{a}}$ Average of three results. Data has been corrected for volume (i.e. divided ICP-ES supernate data by $470 \mathrm{~mL} / 120 \mathrm{~mL}$ to obtain concentration in $470 \mathrm{~mL}$ ).

${ }^{\mathrm{b}}$ Average of two results

As can be seen in Table 4 and Table 5, the concentrations for the majority of the elements are increasing with time even though the elements are present in the supernate prior to the addition of acid for both cases. Some elements appear to be rapidly increasing in concentration in the supernate, such as Fe and $\mathrm{Mn}$, and others appear to be dissolving slowly such as $\mathrm{Na}$ and $\mathrm{Si}$. The dissolution of these elements is dependant on their chemical form. The Fe and Mn in the OGCT solids could be spinels or oxides which would be readily dissolved in strong acids. The $\mathrm{Na}$ and $\mathrm{Si}$ are probably oxides of the frit and have very low solubility in strong acids. It was also noted that the Na concentration in Table 4 appears to go up and then back down at 24 hours and the Si concentration in Table 5 appears to have reached equilibrium for the 8 and 24 hour samples. The changes in the Na concentration could be due to some of the $\mathrm{Na}$ dissolving and then re-precipitating with another component in the supernate or this change could be due to analytical error. The standards submitted for the sets of samples do not indicate that this was an analytical problem. It also appears from the data in Table 4 and Table 5, that the 50wt. \% test dissolved more of the OGCT solids versus the 12 wt.\% test. This can be seen readily in Figure 6, Figure 7, and Figure 8. The data used in these figures have been corrected using the initial concentrations found in the second column of Table 4 and Table 5 . Figure 6 graphically depicts the concentration data for time zero, 2 hour, 8 hour, and 24 hour from Table 4 and Table 5 for Al, Mg, and Mn. Figure 7 graphically depicts the concentration data for time zero, 2 hour, 8 hour, and 24 hour from Table 4 and Table 5 for Na, Ni, and Si. Figure 8 graphically depicts the concentration data for time zero, 2 hour, 8 hour, and 24 hour from Table 4 and Table 5 for Fe. 


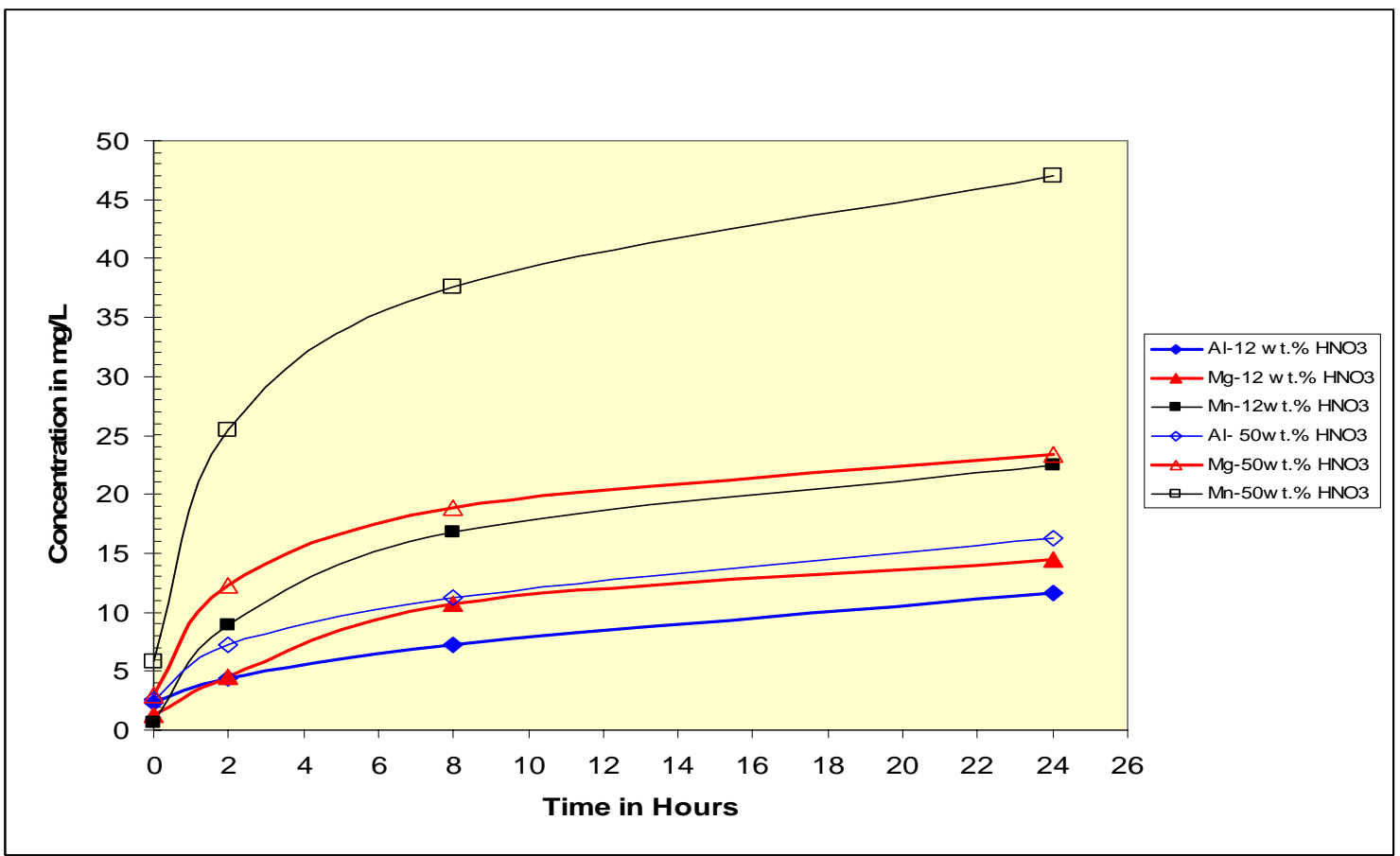

Figure 6 - Comparison of the Concentration Data for Al, Mg, and Mn taken at Time Zero, 2 Hour, 8 Hour, and 24 Hour for the 12 wt.\% and 50 wt.\% Nitric Acid Cases

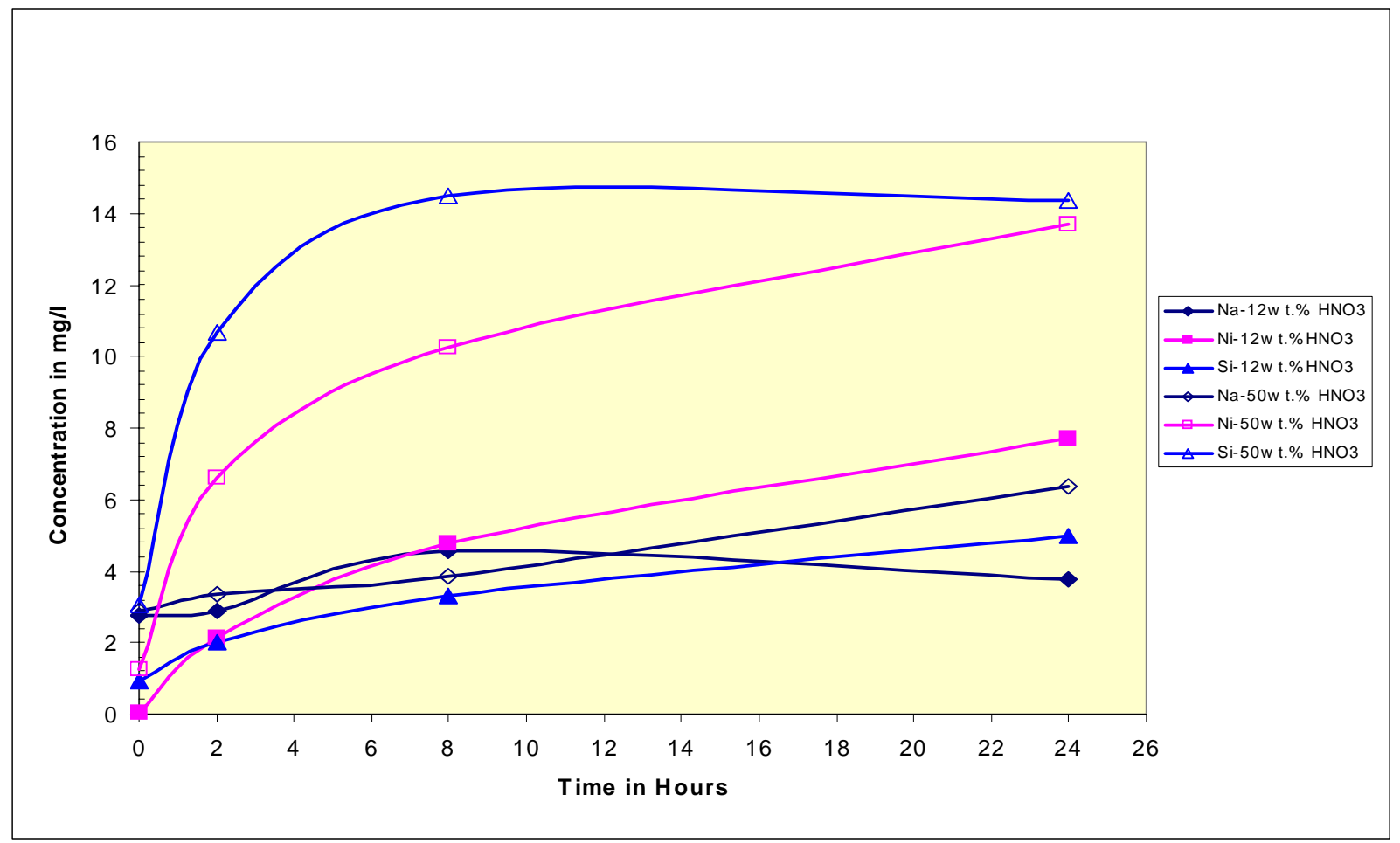

Figure 7 - Comparison of the Concentration Data for Na, Ni, and Si taken at Time Zero, 2 Hour, 8 Hour, and 24 Hour for the 12 wt.\% and 50 wt.\% Nitric Acid Cases 


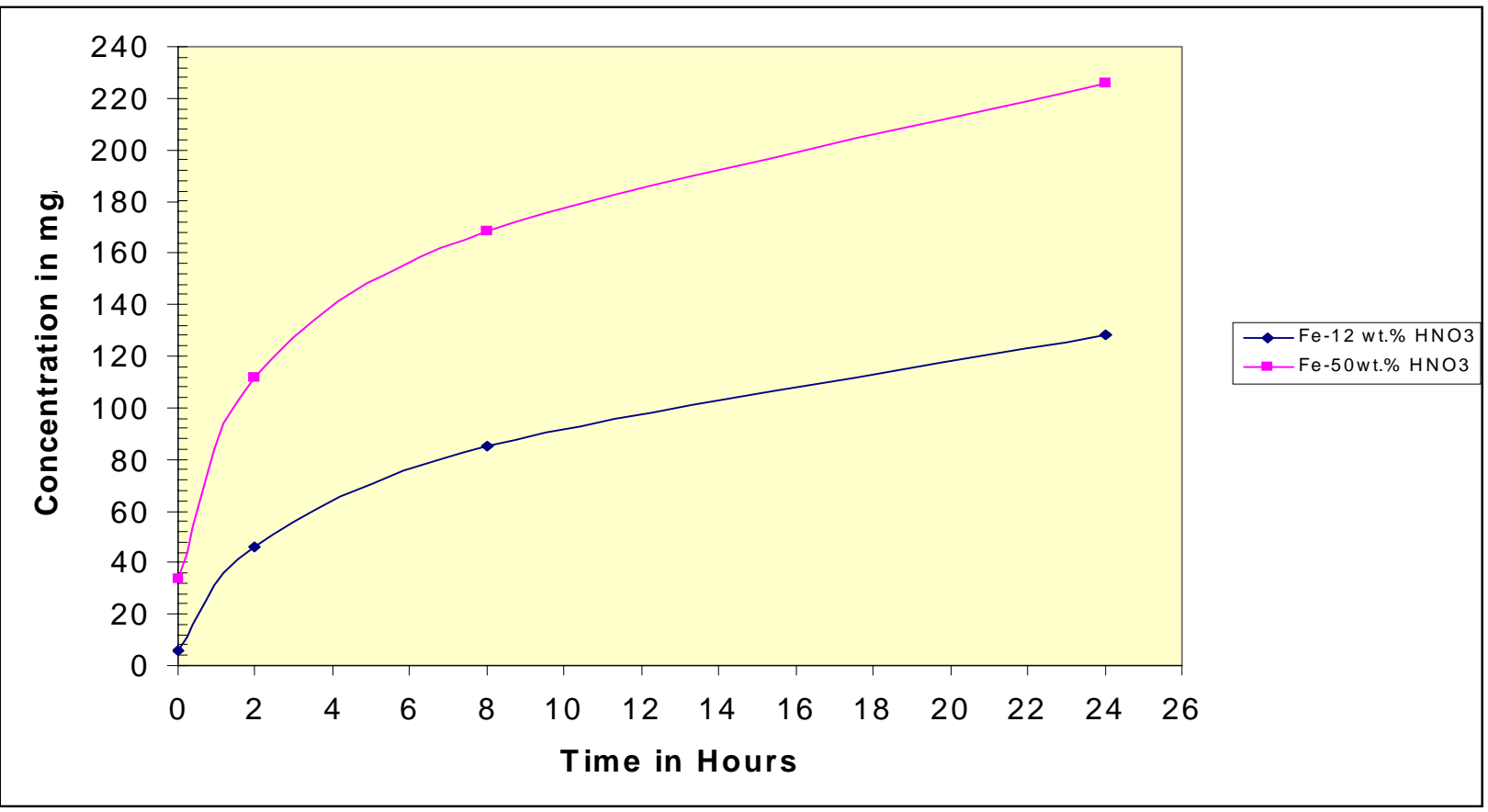

Figure 8 - Comparison of the Concentration Data for Fe taken at Time Zero, 2 Hour, 8 Hour, and 24 Hour for the 12 wt. \% and 50 wt. \% Nitric Acid Cases

\subsection{Amount of Al, Fe, Mg, Mn, Na, Ni, and Si Dissolved During the 12 wt.\% and 50 wt. \% Nitric Acid Test Cases}

The data reported in Table 4 and Table 5 were used to calculate the mass of $\mathrm{Al}, \mathrm{Fe}, \mathrm{Mg}, \mathrm{Mn}, \mathrm{Na}, \mathrm{Ni}$, and Si in the $12 \mathrm{wt} . \%$ and $50 \mathrm{wt} . \%$ nitric acid tests. These data along with the calculated weight percent solids and densities for the nitric acid solutions were used to convert the supernate concentrations to a slurry basis. Upon conversion to a slurry basis, the results were compared to each other and a percent difference was calculated. The results of the $12 \mathrm{wt} . \%$ and $50 \mathrm{wt} . \%$ nitric acid testing can be found in Table 6. 
Table 6 - Comparison of the Total Grams Dissolved After 24 Hours for the 12 wt.\% and 50 wt.\% Nitric Acid Test Cases

\begin{tabular}{|c|c|c|c|}
\hline Element & $\begin{array}{c}12 \% \text { HNO3 } \\
\text { Grams Dissolved } \\
\text { From Time Zero } \\
\text { to } 24 \text { Hours }\end{array}$ & $\begin{array}{c}\text { 50\% HNO3 Grams } \\
\text { Dissolved From } \\
\text { Time Zero to } 24 \\
\text { Hours }\end{array}$ & 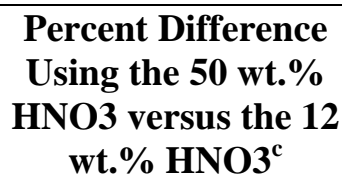 \\
\hline $\mathrm{Al}$ & 3.52E-03 & 4.93E-03 & $2.85 \mathrm{E}+01$ \\
\hline $\mathrm{Fe}$ & 3.89E-02 & 6.82E-02 & $4.30 \mathrm{E}+01$ \\
\hline $\mathrm{Mg}$ & 4.35E-03 & 7.09E-03 & $3.87 \mathrm{E}+01$ \\
\hline $\mathrm{Mn}$ & 6.82E-03 & 1.42E-02 & $5.21 \mathrm{E}+01$ \\
\hline $\mathrm{Na}$ & 1.13E-03 & 1.93E-03 & $4.13 \mathrm{E}+01$ \\
\hline $\mathrm{Ni}$ & 2.34E-03 & 4.14E-03 & $4.35 \mathrm{E}+01$ \\
\hline $\mathrm{Si}$ & $1.50 \mathrm{E}-03$ & 4.36E-03 & $6.55 \mathrm{E}+01$ \\
\hline
\end{tabular}

${ }^{a}$ Example for Al: Subtracted initial minus 24 hour concentration in Table 4 (18.3-6.66)*(1.009 mL of supernate/mL of slurry $*(1 \mathrm{~g} / 1000 \mathrm{mg}) *(1 \mathrm{~L} / 1000 \mathrm{~mL}) * 300 \mathrm{~mL}$. The same protocol was used for the remaining elements. It should be noted that the ratio of $\mathrm{mL}$ of supernate/mL of slurry should not exceed 1.00 . If it exceeds 1.00 , it is probably due to analytical error associated with the measurements completed for the sample.

${ }^{\mathrm{b}}$ Example for Al: Subtracted initial minus 24 hour concentration in Table 5 (22.9-6.66)*(1.008 mL of supernate/mL of slurry $)^{*}(1 \mathrm{~g} / 1000 \mathrm{mg}) *(1 \mathrm{~L} / 1000 \mathrm{~mL}) * 300 \mathrm{~mL}$. The same protocol was used for the remaining elements. . It should be noted that the ratio of $\mathrm{mL}$ of supernate/mL of slurry should not exceed 1.00 . If it exceeds 1.00 , it is probably due to analytical error associated with the measurements completed for the sample.

c (Column 3 - Column 2/ Column 3)*100

From the results in Table 6, the 50 wt. \% nitric acid case dissolved more of the OGCT solids than the 12 wt. \% nitric acid case for all of the elements in the table. The acid concentration (14.8 wt. \%) used in the DWPF falls between the two acid concentrations (9.2 wt. \% and $39.6 \mathrm{wt}$. \%) tested at SRNL. If DWPF maintained their acid concentration, but increased the residence time to 24 hours, one would expect the total grams dissolved to fall between the values reported in Table 6. If a higher dissolution of the OGCT solids is desired, then it is recommended that DWPF increase the acid concentration (up to $39.6 \mathrm{wt} . \%$ ) as well as the residence time (24 hours).

\subsection{CONCLUSIONS}

Several conclusions and observations were made from the data presented in Section 3.0. A list of these conclusions and observations are presented below.

- The OGCT samples contained visible brown solids that appeared to be made up of fine particulates that settled very slowly. However, during the mixing and sampling process, the presence of fast settling particulates was also clearly indicated.

- The entrained solids in the OGCT sample are composed of mainly Fe, Si, Mn, Al, Ni, and Mg with Fe being the dominant component. The results of the characterization show slight differences when compared to a previous OGCT sample ${ }^{1}$, however, the major components of both samples are similar.

- The results for the Contained X-Ray Diffraction (CXRD) indicated that two forms of Fe (hematite and magnetite) are present in the solids of the OGCT sample. These samples were compared to previously published results by C.M. Jantzen for samples from the Scaled Glass Melter Off-Gas Condensate Tank (SGMOGCT) ${ }^{2}$. C.M. Jantzen's results indicated spinel and $\mathrm{SiO}_{2}$ as the main components of the solids from the SGMOGCT. 
- Contained Scanning Electron Microscopy (CSEM) results for the OGCT solids were consistent with C.M. Jantzen's analysis of the SGMOGCT results. Deposits rich in Si as well as spinel forming elements (Fe, $\mathrm{Al}, \mathrm{Mn}$, and $\mathrm{Ni}$ ) were identified in the OGCT samples.

- For both nitric acid dissolutions cases (50\% and 12\%), some elements appear to be rapidly increasing in concentration in the supernate, such as Fe and Mn, and others appear to be dissolving slowly such as $\mathrm{Na}$ and $\mathrm{Si}$. The dissolution of these elements is dependant on their chemical form.

- The residence time and the concentration of the nitric acid used for the OGCT cleaning procedure are important variables. Extending the residence time from 8 hours to 24 hours, results in the dissolution of more of the OGCT solids. Increasing the nitric acid concentration from $12 \%$ to $50 \%$ dissolved $45 \%$ (average of seven elements) more of the OGCT solids.

\subsection{RECOMMENDATIONS}

- In order to dissolve more of the OGCT solids during a tank cleanout, it is recommended that the nitric acid concentration be increased to $39.6 \mathrm{wt}$. \% and the residence time to 24 hours. If it is not desired to change the nitric acid concentration, then the residence time should be extended to 24 hours to dissolve as much of the OGCT solids as possible.

\subsection{ACKNOWLEDGEMENTS}

The authors of this report would like to thank the Shielded Cells technicians, ITS technicians, and ADS for their dedication and hard work. 


\subsection{REFERENCES}

${ }^{1}$ T.L. Fellinger and N.E. Bibler "Results for the DWPF Slurry Mix Evaporator Condensate Tank, Off Gas Condensate Tank, and Recycle Collection Tank Samples (U), WSRC-TR-2004-00577, Rev. 0, December 21, 2004.

${ }^{2}$ C.M. Jantzen, “Glass Melter Off-Gas System Pluggages: Cause, Significance, and Remediation (U), WSRC-TR-90-205, Rev.0, March 1991.

${ }^{3}$ V. R. Buch, “Off Gas Condensate Tank Water Sample”, HLW/DWPF-TAR-2005-0001, Rev.0, February 2, 2005.

${ }^{4}$ J.C. Marek, “Correction Factor for Soluble and Insoluble Solids (U)”, SRTC-PTD-92-0040, August 28, 1992. 
WSRC-TR-2005-00141

Revision 0

\section{APPENDIX A}

DATA FROM THE CHARACTERIZATION AND DISSOLUTION TESTING

Page 23 
Table A-1 - Averages, Percent Relative Standard Deviations, Blanks, and Standards for the OGCT Data

\begin{tabular}{|c|c|c|c|c|c|c|c|c|}
\hline Analyte & $\begin{array}{c}\text { 1st } \\
\text { Replicate } \\
\text { (mg/L) }\end{array}$ & $\begin{array}{c}\text { 2nd } \\
\text { Replicate } \\
\text { (mg/L) }\end{array}$ & $\begin{array}{c}\text { 3rd } \\
\text { Replicate } \\
(\mathrm{mg} / \mathrm{L})\end{array}$ & $\begin{array}{c}\text { Average } \\
\text { (mg/L) }\end{array}$ & $\%$ RSD & $\begin{array}{c}\text { Blank } \\
(\mathrm{mg} / \mathrm{L})\end{array}$ & $\begin{array}{c}\text { ICP-ES Std } \\
(\mathrm{mg} / \mathrm{L})\end{array}$ & \begin{tabular}{|c|} 
ICP-ES Std \\
Comp \\
$(\mathrm{mg} / \mathrm{L})$
\end{tabular} \\
\hline $\begin{array}{l}\text { Wt.\% Dissolved } \\
\text { Solids of Supernate }\end{array}$ & $0.00 \%$ & $0.00 \%$ & $0.00 \%$ & $0.00 \%$ & - & - & - & - \\
\hline $\begin{array}{l}\text { Wt. \% Total Solids of } \\
\text { Slurry }\end{array}$ & $0.38 \%$ & $0.36 \%$ & - & $0.37 \%$ & $3.8 \%$ & - & - & - \\
\hline Wt.\% Insoluble Solids & $0.38 \%$ & $0.36 \%$ & - & $0.37 \%$ & $3.8 \%$ & - & - & - \\
\hline Wt.\% Soluble Solids & $0.00 \%$ & $0.00 \%$ & $0.00 \%$ & $0.00 \%$ & - & - & - & - \\
\hline $\begin{array}{c}\text { Wt.\% Insoluble Solids } \\
\text { - Direct Measurement }\end{array}$ & $0.41 \%$ & $0.41 \%$ & - & $0.41 \%$ & $0.0 \%$ & - & - & - \\
\hline Slurry Density, g/mL & 0.99 & 0.99 & 1.01 & 1.00 & $1.2 \%$ & - & - & - \\
\hline $\begin{array}{l}\text { Supernate Density, } \\
\mathrm{g} / \mathrm{mL}\end{array}$ & 1.01 & 0.99 & 1.00 & 1.00 & $1.0 \%$ & - & - & - \\
\hline $\mathrm{pH}$ & $2.52 \mathrm{E}+00$ & - & - & - & - & - & - & - \\
\hline Al & $2.61 \mathrm{E}+01$ & $2.62 \mathrm{E}+01$ & $2.60 \mathrm{E}+01$ & $2.61 \mathrm{E}+01$ & $0.4 \%$ & $<4.6 \mathrm{E}-02$ & $3.98 \mathrm{E}+00$ & $4.00 \mathrm{E}+00$ \\
\hline $\mathrm{Ca}$ & $5.96 \mathrm{E}+00$ & $6.02 \mathrm{E}+00$ & $5.97 \mathrm{E}+00$ & $5.98 \mathrm{E}+00$ & $0.5 \%$ & $<1.0 \mathrm{E}-02$ & $<1.0 \mathrm{E}-02$ & - \\
\hline $\mathrm{Fe}$ & $1.90 \mathrm{E}+00$ & $1.91 \mathrm{E}+00$ & $1.87 \mathrm{E}+00$ & $1.89 \mathrm{E}+00$ & $1.1 \%$ & $<1.3 \mathrm{E}-02$ & $4.09 \mathrm{E}+00$ & $4.00 \mathrm{E}+00$ \\
\hline $\mathrm{Mg}$ & $3.87 \mathrm{E}+00$ & $3.89 \mathrm{E}+00$ & $3.79 \mathrm{E}+00$ & $3.85 \mathrm{E}+00$ & $1.4 \%$ & $<4.0 \mathrm{E}-03$ & $<4.0 \mathrm{E}-03$ & - \\
\hline $\mathrm{Mn}$ & $8.13 E+00$ & $8.19 \mathrm{E}+00$ & $7.99 \mathrm{E}+00$ & $8.10 \mathrm{E}+00$ & $1.3 \%$ & $<2.0 \mathrm{E}-03$ & $<2.0 \mathrm{E}-03$ & - \\
\hline $\mathrm{Na}$ & $4.17 \mathrm{E}+01$ & $4.15 \mathrm{E}+01$ & $4.17 \mathrm{E}+01$ & $4.16 \mathrm{E}+01$ & $0.3 \%$ & $<3.9 \mathrm{E}-01$ & $7.84 \mathrm{E}+01$ & $8.10 \mathrm{E}+01$ \\
\hline $\mathrm{Ni}$ & 8.51E-01 & 8.53E-01 & 8.48E-01 & 8.51E-01 & $0.3 \%$ & $<1.0 \mathrm{E}-01$ & $<1.0 \mathrm{E}-01$ & - \\
\hline$S$ & $1.05 \mathrm{E}+01$ & $9.92 \mathrm{E}+00$ & $1.01 \mathrm{E}+01$ & $1.02 \mathrm{E}+01$ & $2.9 \%$ & $<9.5 \mathrm{E}-02$ & $<9.5 \mathrm{E}-02$ & - \\
\hline $\mathrm{Si}$ & $1.19 \mathrm{E}+01$ & $1.20 \mathrm{E}+01$ & $1.16 \mathrm{E}+01$ & $1.18 \mathrm{E}+01$ & $1.8 \%$ & $<5.4 \mathrm{E}-01$ & $5.27 \mathrm{E}+01$ & $5.00 \mathrm{E}+01$ \\
\hline $\mathrm{U}$ & $1.63 \mathrm{E}+01$ & $1.63 \mathrm{E}+01$ & $1.63 \mathrm{E}+01$ & $1.63 \mathrm{E}+01$ & $0.0 \%$ & $<2.2 \mathrm{E}-01$ & $<2.2 \mathrm{E}-01$ & - \\
\hline Chloride & $2.00 \mathrm{E}+00$ & $2.00 \mathrm{E}+00$ & $2.00 \mathrm{E}+00$ & $2.00 \mathrm{E}+00$ & $0.0 \%$ & $<2.0 \mathrm{E}+00$ & $2.00 \mathrm{E}+00$ & $2.00 \mathrm{E}+00$ \\
\hline Formate & $2.00 \mathrm{E}+00$ & $2.00 \mathrm{E}+00$ & $2.00 \mathrm{E}+00$ & $2.00 \mathrm{E}+00$ & $0.0 \%$ & $<2.0 \mathrm{E}+00$ & $2.00 \mathrm{E}+00$ & $2.00 \mathrm{E}+00$ \\
\hline Fluoride & $5.00 \mathrm{E}+00$ & $5.00 \mathrm{E}+00$ & $5.00 \mathrm{E}+00$ & $5.00 \mathrm{E}+00$ & $0.0 \%$ & $<2.0 \mathrm{E}+00$ & $5.00 \mathrm{E}+00$ & $5.00 \mathrm{E}+00$ \\
\hline Nitrate & $5.07 \mathrm{E}+02$ & $5.00 \mathrm{E}+02$ & $5.38 \mathrm{E}+02$ & $5.15 \mathrm{E}+02$ & $3.9 \%$ & $<1.0 \mathrm{E}+01$ & $5.07 \mathrm{E}+02$ & $5.00 \mathrm{E}+02$ \\
\hline Nitrite & $<1.0 \mathrm{E}+01$ & $<1.0 \mathrm{E}+01$ & $<1.0 \mathrm{E}+01$ & $<1.0 \mathrm{E}+01$ & - & $<1.0 \mathrm{E}+01$ & $<1.0 \mathrm{E}+01$ & $<1.0 \mathrm{E}+01$ \\
\hline Oxalate & $<1.0 \mathrm{E}+01$ & $<1.0 \mathrm{E}+01$ & $<1.0 \mathrm{E}+01$ & $<1.0 \mathrm{E}+01$ & - & $<1.0 \mathrm{E}+01$ & $<1.0 \mathrm{E}+01$ & $<1.0 \mathrm{E}+01$ \\
\hline Phosphate & $<1.0 \mathrm{E}+01$ & $<1.0 \mathrm{E}+01$ & $<1.0 \mathrm{E}+01$ & $<1.0 \mathrm{E}+01$ & - & $<1.0 \mathrm{E}+01$ & $<1.0 \mathrm{E}+01$ & $<1.0 \mathrm{E}+01$ \\
\hline Sulfate & $2.80 \mathrm{E}+01$ & $2.80 \mathrm{E}+01$ & $3.00 \mathrm{E}+01$ & $2.87 \mathrm{E}+01$ & $4.0 \%$ & $<5.0 \mathrm{E}+00$ & $2.80 \mathrm{E}+01$ & $2.80 \mathrm{E}+01$ \\
\hline
\end{tabular}


Table A- 2 - Results of the Aqua-Regia Digestion of the OGCT Solids

\begin{tabular}{|c|c|c|c|c|c|c|c|c|c|c|c|c|}
\hline Analyte & $\begin{array}{c}\text { 1st } \\
\text { Replicate } \\
\text { (wt \%) }\end{array}$ & $\begin{array}{c}\text { 2nd } \\
\text { Replicate } \\
(w t \%)\end{array}$ & $\begin{array}{c}\text { 3rd } \\
\text { Replicate } \\
\text { (wt\%) } \\
\end{array}$ & $\begin{array}{c}\text { Average } \\
\text { (wt\%) }\end{array}$ & $\%$ RSD & $\begin{array}{r}\text { Blank } \\
(\text { wt \%) }\end{array}$ & \begin{tabular}{|c|}
$1^{\text {st }}$ \\
ICP-ES Std \\
$(\mathrm{mg} / \mathrm{L})$
\end{tabular} & $\begin{array}{c}2^{\text {nd }} \\
\text { ICP-ES Std } \\
(\mathrm{mg} / \mathrm{L}) \\
\end{array}$ & $\begin{array}{c}\text { ICP-ES Std } \\
\text { Comp } \\
(\mathrm{mg} / \mathrm{L})\end{array}$ & $\begin{array}{c}1^{\text {st }} \\
\text { Glass Std } \\
(w t \%) \\
\end{array}$ & $\begin{array}{c}2^{\text {nd }} \\
\text { Glass Std } \\
(w t \%) \\
\end{array}$ & $\begin{array}{c}\text { Glass Std } \\
\text { Comp } \\
\text { (wt\%) } \\
\end{array}$ \\
\hline $\mathrm{Ag}$ & $2.46 \mathrm{E}-02$ & $2.43 \mathrm{E}-02$ & $2.54 \mathrm{E}-02$ & 2.48E-02 & $2.4 \%$ & $<2.0 \mathrm{E}-03$ & $<2.0 \mathrm{E}-02$ & $<2.0 \mathrm{E}-02$ & - & $1.57 \mathrm{E}-03$ & $1.56 \mathrm{E}-03$ & - \\
\hline $\mathrm{Al}$ & $2.55 \mathrm{E}+00$ & $2.53 \mathrm{E}+00$ & $2.58 \mathrm{E}+00$ & $2.55 \mathrm{E}+00$ & $1.1 \%$ & $<8.4 \mathrm{E}-03$ & $4.32 \mathrm{E}+00$ & $4.37 \mathrm{E}+00$ & $4.00 \mathrm{E}+00$ & $2.55 \mathrm{E}+00$ & $2.57 \mathrm{E}+00$ & $2.50 \mathrm{E}+00$ \\
\hline B & 2.22E-02 & $3.20 \mathrm{E}-02$ & $3.41 \mathrm{E}-02$ & 2.94E-02 & $22 \%$ & $<1.1 \mathrm{E}-02$ & $2.05 E+01$ & $2.05 \mathrm{E}+01$ & $2.00 \mathrm{E}+01$ & $2.72 E+00$ & $2.72 \mathrm{E}+00$ & $2.69 \mathrm{E}+00$ \\
\hline $\mathrm{Ba}$ & 4.72E-02 & 4.50E-02 & 4.77E-02 & 4.66E-02 & $3.1 \%$ & $<1.6 \mathrm{E}-03$ & $<1.6 \mathrm{E}-02$ & $<1.6 \mathrm{E}-02$ & - & 7.87E-02 & 7.93E-02 & 7.90E-02 \\
\hline Be & 4.65E-04 & $5.60 \mathrm{E}-04$ & 5.83E-04 & 5.36E-04 & $12 \%$ & $<1.0 \mathrm{E}-04$ & $<1.0 \mathrm{E}-03$ & $<1.0 \mathrm{E}-03$ & - & 2.09E-03 & $2.11 \mathrm{E}-03$ & - \\
\hline $\mathrm{Ca}$ & 2.03E-01 & 2.03E-01 & 2.07E-01 & 2.04E-01 & $1.0 \%$ & $8.20 \mathrm{E}-03$ & $<1.8 \mathrm{E}-02$ & $<1.8 \mathrm{E}-02$ & - & $1.01 \mathrm{E}+00$ & $1.02 \mathrm{E}+00$ & $1.02 \mathrm{E}+00$ \\
\hline $\mathrm{Cd}$ & $3.60 \mathrm{E}-01$ & 3.56E-01 & 3.84E-01 & 3.67E-01 & $4.2 \%$ & $<2.6 \mathrm{E}-03$ & $<2.6 \mathrm{E}-02$ & $<2.6 \mathrm{E}-02$ & - & $1.24 \mathrm{E}-03$ & $1.37 \mathrm{E}-03$ & - \\
\hline $\mathrm{Ce}$ & $6.12 \mathrm{E}-02$ & 6.15E-02 & 6.83E-02 & 6.37E-02 & $6.2 \%$ & $<2.7 \mathrm{E}-02$ & $<2.7 \mathrm{E}-01$ & $<2.7 \mathrm{E}-01$ & - & 1.73E-02 & $1.61 \mathrm{E}-02$ & - \\
\hline $\mathrm{Cr}$ & 8.68E-02 & 8.56E-02 & $9.21 \mathrm{E}-02$ & 8.82E-02 & $3.9 \%$ & $<1.1 \mathrm{E}-02$ & $<1.1 \mathrm{E}-01$ & $<1.1 \mathrm{E}-01$ & - & 5.74E-02 & $5.66 \mathrm{E}-02$ & $6.40 \mathrm{E}-02$ \\
\hline $\mathrm{Cu}$ & $3.91 \mathrm{E}-02$ & 3.79E-02 & 3.85E-02 & 3.85E-02 & $1.5 \%$ & $2.00 \mathrm{E}-03$ & $<2.0 \mathrm{E}-02$ & $<2.0 \mathrm{E}-02$ & - & 2.69E-03 & 2.62E-03 & $3.00 \mathrm{E}-03$ \\
\hline $\mathrm{Fe}$ & $3.74 \mathrm{E}+01$ & $3.74 \mathrm{E}+01$ & $3.85 \mathrm{E}+01$ & $3.78 \mathrm{E}+01$ & $1.7 \%$ & $1.01 \mathrm{E}-02$ & $4.10 \mathrm{E}+00$ & $4.75 \mathrm{E}+00$ & $4.00 \mathrm{E}+00$ & $9.52 \mathrm{E}+00$ & $9.57 \mathrm{E}+00$ & $9.79 \mathrm{E}+00$ \\
\hline Gd & $2.45 \mathrm{E}-02$ & 2.44E-02 & $2.50 \mathrm{E}-02$ & $2.46 \mathrm{E}-02$ & $1.2 \%$ & $<3.4 \mathrm{E}-03$ & $<3.4 \mathrm{E}-02$ & $<3.4 \mathrm{E}-02$ & - & 5.46E-03 & $5.43 \mathrm{E}-03$ & - \\
\hline K & $<1.5 \mathrm{E}-01$ & $<1.6 \mathrm{E}-01$ & $<1.9 \mathrm{E}-01$ & $<1.7 \mathrm{E}-01$ & - & $<1.6 \mathrm{E}-01$ & $9.57 \mathrm{E}+00$ & $9.67 \mathrm{E}+00$ & $1.00 \mathrm{E}+01$ & $2.30 \mathrm{E}+00$ & $2.41 \mathrm{E}+00$ & $2.26 \mathrm{E}+00$ \\
\hline $\mathrm{La}$ & $1.93 \mathrm{E}-02$ & 2.03E-02 & $2.04 \mathrm{E}-02$ & $2.00 \mathrm{E}-02$ & $3.0 \%$ & $<1.0 \mathrm{E}-02$ & $<1.0 \mathrm{E}-01$ & $<1.0 \mathrm{E}-01$ & - & 4.82E-03 & $4.80 \mathrm{E}-03$ & - \\
\hline $\mathrm{Li}$ & $2.59 \mathrm{E}-01$ & 2.62E-01 & 2.69E-01 & 2.63E-01 & $1.9 \%$ & $<9.6 \mathrm{E}-03$ & $9.83 \mathrm{E}+00$ & $9.87 \mathrm{E}+00$ & $1.00 \mathrm{E}+01$ & $1.52 \mathrm{E}+00$ & $1.54 \mathrm{E}+00$ & $1.49 \mathrm{E}+00$ \\
\hline $\mathrm{Mg}$ & $2.03 \mathrm{E}+00$ & $2.02 \mathrm{E}+00$ & $2.10 \mathrm{E}+00$ & $2.05 \mathrm{E}+00$ & $2.0 \%$ & $2.60 \mathrm{E}-03$ & $<8.0 \mathrm{E}-03$ & $2.10 \mathrm{E}-02$ & - & 5.06E-01 & 5.08E-01 & $5.20 \mathrm{E}-01$ \\
\hline $\mathrm{Mn}$ & $5.01 \mathrm{E}+00$ & $5.01 \mathrm{E}+00$ & $5.15 \mathrm{E}+00$ & $5.05 \mathrm{E}+00$ & $1.6 \%$ & $9.00 \mathrm{E}-04$ & $<4.0 \mathrm{E}-03$ & 8.50E-02 & - & $1.41 \mathrm{E}+00$ & $1.42 \mathrm{E}+00$ & $1.46 \mathrm{E}+00$ \\
\hline Mo & $1.21 \mathrm{E}-01$ & $1.16 \mathrm{E}-01$ & $1.25 \mathrm{E}-01$ & $1.21 \mathrm{E}-01$ & $3.8 \%$ & $<2.7 \mathrm{E}-02$ & $<2.7 \mathrm{E}-01$ & $<2.7 \mathrm{E}-01$ & - & 3.43E-02 & 3.50E-02 & - \\
\hline
\end{tabular}


Table A- 2 - Results of the Aqua-Regia Digestion of the OGCT Solids (Continued)

\begin{tabular}{|c|c|c|c|c|c|c|c|c|c|c|c|c|}
\hline Analyte & $\begin{array}{c}\text { 1st } \\
\text { Replicate } \\
\text { (wt\%) }\end{array}$ & $\begin{array}{c}\text { 2nd } \\
\text { Replicate } \\
\text { (wt \%) }\end{array}$ & $\begin{array}{c}\text { 3rd } \\
\text { Replicate } \\
\text { (wt\%) }\end{array}$ & $\begin{array}{c}\text { Average } \\
\text { (wt\%) }\end{array}$ & $\%$ RSD & $\begin{array}{l}\text { Blank } \\
\text { (wt\%) }\end{array}$ & \begin{tabular}{|c|}
$1^{\text {st }}$ \\
ICP-ES Std \\
$(\mathrm{mg} / \mathrm{L})$ \\
\end{tabular} & $\begin{array}{c}2^{\text {nd }} \\
\text { ICP-ES Std } \\
\text { (mg/L) }\end{array}$ & \begin{tabular}{|c|} 
ICP-ES Std \\
$\begin{array}{c}\text { Comp } \\
(\mathrm{mg} / \mathrm{L})\end{array}$ \\
\end{tabular} & $\begin{array}{c}1^{\text {st }} \\
\text { Glass Std } \\
(w t \%)\end{array}$ & $\begin{array}{c}2^{\text {nd }} \\
\text { Glass Std } \\
(w t \%)\end{array}$ & $\begin{array}{c}\text { Glass Std } \\
\text { Comp } \\
(w t \%)\end{array}$ \\
\hline $\mathrm{Na}$ & 4.75E-01 & 4.22E-01 & $5.22 \mathrm{E}-01$ & 4.73E-01 & $11 \%$ & $<7.1 \mathrm{E}-02$ & $7.47 \mathrm{E}+01$ & $7.76 \mathrm{E}+01$ & $8.10 \mathrm{E}+01$ & $7.99 \mathrm{E}+00$ & $8.05 E+00$ & $8.52 E+00$ \\
\hline $\mathrm{Ni}$ & $2.04 \mathrm{E}+00$ & $2.02 \mathrm{E}+00$ & $2.09 \mathrm{E}+00$ & $2.05 E+00$ & $1.6 \%$ & $<1.9 \mathrm{E}-02$ & $<1.9 \mathrm{E}-01$ & $<1.9 \mathrm{E}-01$ & - & 8.11E-01 & 8.09E-01 & - \\
\hline $\mathrm{P}$ & 4.69E-01 & 4.41E-01 & 4.14E-01 & 4.41E-01 & $6.3 \%$ & $<5.3 \mathrm{E}-02$ & $<5.3 \mathrm{E}-01$ & $<5.3 \mathrm{E}-01$ & - & $1.08 \mathrm{E}-01$ & 1.31E-01 & $1.10 \mathrm{E}-01$ \\
\hline $\mathrm{Pb}$ & $<9.3 \mathrm{E}-02$ & 1.03E-01 & $<1.2 \mathrm{E}-01$ & 1.03E-01 & $11 \%$ & $<9.6 \mathrm{E}-02$ & $<9.6 \mathrm{E}-01$ & $<9.6 \mathrm{E}-01$ & - & $<3.8 \mathrm{E}-02$ & $<3.7 \mathrm{E}-02$ & - \\
\hline S & $2.00 \mathrm{E}-01$ & $1.90 \mathrm{E}-01$ & 2.11E-01 & 2.00E-01 & $5.3 \%$ & $<1.7 \mathrm{E}-02$ & $<1.7 \mathrm{E}-01$ & $<1.7 \mathrm{E}-01$ & - & 3.12E-02 & 3.64E-02 & - \\
\hline $\mathrm{Sb}$ & $1.42 \mathrm{E}-01$ & 1.43E-01 & $1.47 \mathrm{E}-01$ & $1.44 \mathrm{E}-01$ & $1.7 \%$ & $<1.0 \mathrm{E}-02$ & $<1.0 \mathrm{E}-01$ & $<1.0 \mathrm{E}-01$ & - & 4.54E-02 & 4.57E-02 & - \\
\hline $\mathrm{Si}$ & $3.50 \mathrm{E}-01$ & 3.25E-01 & 7.57E-01 & 4.77E-01 & $51 \%$ & $<9.7 \mathrm{E}-02$ & $5.23 \mathrm{E}+01$ & $5.23 \mathrm{E}+01$ & $5.00 \mathrm{E}+01$ & $2.58 \mathrm{E}-01$ & $2.50 \mathrm{E}-01$ & $2.24 \mathrm{E}+01$ \\
\hline Sn & $1.74 \mathrm{E}-01$ & 1.77E-01 & $1.81 \mathrm{E}-01$ & 1.77E-01 & $2.0 \%$ & $<6.0 \mathrm{E}-02$ & $<6.0 \mathrm{E}-01$ & $<6.0 \mathrm{E}-01$ & - & 7.31E-02 & 7.11E-02 & - \\
\hline $\mathrm{Sr}$ & 5.19E-02 & 5.19E-02 & 5.33E-02 & 5.24E-02 & $1.5 \%$ & $<2.0 \mathrm{E}-03$ & $<2.0 \mathrm{E}-02$ & $<2.0 \mathrm{E}-02$ & - & $2.00 \mathrm{E}-01$ & 2.03E-01 & $3.00 \mathrm{E}-03$ \\
\hline $\mathrm{Ti}$ & 3.01E-02 & 3.22E-02 & 3.39E-02 & 3.21E-02 & $6.0 \%$ & $<6.0 \mathrm{E}-04$ & $<6.0 \mathrm{E}-03$ & $<6.0 \mathrm{E}-03$ & - & 5.98E-01 & $5.94 \mathrm{E}-01$ & $6.90 \mathrm{E}-01$ \\
\hline $\mathrm{U}$ & 2.07E-01 & 2.10E-01 & 2.14E-01 & 2.10E-01 & $1.6 \%$ & $<3.9 \mathrm{E}-02$ & $<3.9 \mathrm{E}-01$ & $<3.9 \mathrm{E}-01$ & - & $<1.6 \mathrm{E}-02$ & $<1.5 \mathrm{E}-02$ & - \\
\hline V & 4.88E-03 & 6.48E-03 & $5.24 \mathrm{E}-03$ & 5.54E-03 & $15 \%$ & $<4.0 \mathrm{E}-03$ & $<4.0 \mathrm{E}-02$ & $<4.0 \mathrm{E}-02$ & - & $1.08 \mathrm{E}-02$ & 1.06E-02 & - \\
\hline $\mathrm{Zn}$ & 6.09E-02 & 6.03E-02 & 6.19E-02 & $6.10 \mathrm{E}-02$ & $1.4 \%$ & $<3.0 \mathrm{E}-03$ & $<3.0 \mathrm{E}-02$ & $<3.0 \mathrm{E}-02$ & - & $1.98 \mathrm{E}-02$ & 1.95E-02 & $1.60 \mathrm{E}-02$ \\
\hline $\mathrm{Zr}$ & $1.43 \mathrm{E}-01$ & $1.22 \mathrm{E}-01$ & $1.12 \mathrm{E}-01$ & $1.26 \mathrm{E}-01$ & $13 \%$ & $<1.6 \mathrm{E}-03$ & $<1.6 \mathrm{E}-02$ & $<1.6 \mathrm{E}-02$ & - & 4.90E-02 & $5.70 \mathrm{E}-02$ & $9.60 \mathrm{E}-02$ \\
\hline Pu-239 & 3.05E-02 & 2.92E-02 & 3.04E-02 & $3.00 \mathrm{E}-02$ & $2.4 \%$ & 5.90E-06 & 4.30E-06 & $1.50 \mathrm{E}-06$ & - & 8.43E-06 & 3.79E-06 & - \\
\hline $\mathrm{Pu}-240$ & 3.46E-03 & $2.96 \mathrm{E}-03$ & $2.79 \mathrm{E}-03$ & 3.07E-03 & $11 \%$ & $1.40 \mathrm{E}-06$ & $<1.0 \mathrm{E}-05$ & $<1.0 \mathrm{E}-05$ & - & 6.83E-07 & $<3.9 \mathrm{E}-06$ & - \\
\hline $\mathrm{Pu}-242$ & $1.66 \mathrm{E}-04$ & $1.50 \mathrm{E}-04$ & 1.69E-04 & $1.61 \mathrm{E}-04$ & $6.3 \%$ & $<1.5 \mathrm{E}-05$ & $<1.5 \mathrm{E}-05$ & $<1.5 \mathrm{E}-05$ & - & $<6.0 \mathrm{E}-06$ & $<5.9 \mathrm{E}-06$ & - \\
\hline U-total & $1.78 \mathrm{E}-01$ & $1.76 \mathrm{E}-01$ & $1.72 \mathrm{E}-01$ & $1.75 \mathrm{E}-01$ & $1.6 \%$ & $6.26 \mathrm{E}-04$ & 4.89E-05 & $7.00 \mathrm{E}-05$ & - & $6.04 \mathrm{E}-04$ & $6.02 \mathrm{E}-04$ & - \\
\hline
\end{tabular}


Table A- 2 - Results of the Aqua-Regia Digestion of the OGCT Solids (Continued)

\begin{tabular}{|c|c|c|c|c|c|c|c|c|c|c|c|c|}
\hline Ana & $\begin{array}{c}\text { 1st } \\
\text { Replicate } \\
(\mu \mathrm{Ci} / \mathrm{g})\end{array}$ & $\begin{array}{c}\text { 2nd } \\
\text { Replicate } \\
(\mu \mathrm{Ci} / \mathrm{g})\end{array}$ & $\begin{array}{c}\text { 3rd } \\
\text { Replicate } \\
(\mu \mathrm{Ci} / \mathrm{g})\end{array}$ & $\begin{array}{c}\text { Average } \\
(\mu \mathrm{Ci} / \mathrm{g})\end{array}$ & $\%$ RSD & $\begin{array}{c}\text { Blank } \\
(\mu \mathrm{Ci} / \mathrm{g})\end{array}$ & $\begin{array}{c}1^{\text {st }} \\
\text { ICP-ES Stc } \\
(\mu \mathrm{Ci} / \mathrm{L})\end{array}$ & \begin{tabular}{|c|}
$2^{\text {nd }}$ \\
ICP-ES Std \\
$(\mu \mathrm{Ci} / \mathrm{L})$ \\
\end{tabular} & \begin{tabular}{|c|} 
ICP-ES Std \\
Comp \\
$(\mu \mathrm{Ci} / \mathrm{L})$
\end{tabular} & $\begin{array}{c}1^{\text {st }} \\
\text { Glass Std } \\
(\mu \mathrm{Ci} / \mathrm{g})\end{array}$ & $\begin{array}{c}2^{\text {nd }} \\
\text { Glass Std } \\
(\mu \mathrm{Ci} / \mathrm{g})\end{array}$ & $\begin{array}{c}\text { Glass Std } \\
\text { Comp } \\
(\mu \mathrm{Ci} / \mathrm{g})\end{array}$ \\
\hline Cs-137 & $6.01 \mathrm{E}+01$ & $6.02 \mathrm{E}+01$ & $8.97 \mathrm{E}+01$ & $7.00 \mathrm{E}+01$ & $24 \%$ & 2.43E-01 & $<8.0 \mathrm{E}-03$ & $<9.1 \mathrm{E}-03$ & - & 4.78E-02 & 2.74E-01 & - \\
\hline Eu-154 & $3.01 \mathrm{E}+00$ & $3.06 \mathrm{E}+00$ & $3.07 \mathrm{E}+00$ & $3.05 E+00$ & $1.0 \%$ & $<1.4 \mathrm{E}-02$ & $<8.6 \mathrm{E}-03$ & $<9.1 \mathrm{E}-03$ & - & $<3.9 \mathrm{E}-03$ & $<5.8 \mathrm{E}-03$ & - \\
\hline Co-60 & $3.08 \mathrm{E}+00$ & $3.16 \mathrm{E}+00$ & $3.20 \mathrm{E}+00$ & $3.15 E+00$ & $1.9 \%$ & $<7.7$ & $<5.9 \mathrm{E}-03$ & $<8.6 \mathrm{I}$ & - & $<2.7 \mathrm{E}-03$ & $<2.6 \mathrm{E}-03$ & - \\
\hline Am-241 & $1.53 \mathrm{E}+01$ & $1.56 \mathrm{E}+01$ & $1.53 \mathrm{E}+01$ & $1.54 \mathrm{E}+01$ & $1.0 \%$ & $<4.8 \mathrm{E}-02$ & $<3.1 \mathrm{E}-02$ & $<2.7 \mathrm{E}-02$ & - & $<1.2 \mathrm{E}-02$ & $<2.3 \mathrm{E}-02$ & - \\
\hline
\end{tabular}


Table A- 3 - Results of the Sodium Peroxide Fusion Digestion of the OGCT Solids

\begin{tabular}{|c|c|c|c|c|c|c|c|c|c|c|c|c|}
\hline Analyte & $\begin{array}{c}\text { 1st } \\
\text { Replicate } \\
\text { (wt \%) }\end{array}$ & $\begin{array}{c}\text { 2nd } \\
\text { Replicate } \\
\text { (wt\%) }\end{array}$ & $\begin{array}{c}\text { 3rd } \\
\text { Replicate } \\
(w t \%)\end{array}$ & $\begin{array}{c}\text { Average } \\
\text { (wt\%) }\end{array}$ & $\%$ RSD & $\begin{array}{l}\text { Blank } \\
\text { (wt\%) }\end{array}$ & $\begin{array}{c}1^{\text {st }} \\
\text { ICP-ES Std } \\
(\mathrm{mg} / \mathrm{L})\end{array}$ & $\begin{array}{c}2^{\text {nd }} \\
\text { ICP-ES Std } \\
\text { (mg/L) }\end{array}$ & \begin{tabular}{|c} 
ICP-ES Std \\
Comp \\
$(\mathrm{mg} / \mathrm{L})$
\end{tabular} & $\begin{array}{c}1^{\text {st }} \\
\text { Glass Std } \\
(w t \%)\end{array}$ & $\begin{array}{c}2^{\text {nd }} \\
\text { Glass Std } \\
\text { (wt \%) }\end{array}$ & $\begin{array}{c}\text { Glass Std } \\
\text { Comp } \\
(\mathbf{w t} \%)\end{array}$ \\
\hline $\mathrm{Ag}$ & $2.80 \mathrm{E}-01$ & 2.31E-01 & 1.35E-01 & 2.15E-01 & $34 \%$ & $1.47 \mathrm{E}-01$ & $<2.0 \mathrm{E}-02$ & $<2.0 \mathrm{E}-02$ & - & 2.27E-02 & 2.30E-02 & - \\
\hline $\mathrm{Al}$ & $2.74 \mathrm{E}+00$ & $2.76 \mathrm{E}+00$ & $2.80 \mathrm{E}+00$ & $2.77 \mathrm{E}+00$ & $1.2 \%$ & $<8.4 \mathrm{E}-03$ & $4.29 \mathrm{E}+00$ & $4.34 \mathrm{E}+00$ & $4.00 \mathrm{E}+00$ & $2.74 \mathrm{E}+00$ & $2.87 \mathrm{E}+00$ & $2.50 \mathrm{E}+00$ \\
\hline B & $1.70 \mathrm{E}-01$ & 1.73E-01 & $1.68 \mathrm{E}-01$ & $1.70 \mathrm{E}-01$ & $1.5 \%$ & $<1.1 \mathrm{E}-02$ & $2.05 E+01$ & $2.03 E+01$ & $2.00 \mathrm{E}+01$ & $2.70 \mathrm{E}+00$ & $2.71 \mathrm{E}+00$ & $2.69 \mathrm{E}+00$ \\
\hline $\mathrm{Ba}$ & 4.94E-02 & 4.76E-02 & 4.94E-02 & 4.88E-02 & $2.1 \%$ & $4.20 \mathrm{E}-03$ & $<1.6 \mathrm{E}-02$ & $<1.6 \mathrm{E}-02$ & - & 7.57E-02 & 7.40E-02 & 7.90E-02 \\
\hline $\mathrm{Be}$ & 6.57E-04 & 6.48E-04 & $6.25 \mathrm{E}-04$ & $6.43 \mathrm{E}-04$ & $2.6 \%$ & $2.00 \mathrm{E}-04$ & $<1.0 \mathrm{E}-03$ & $<1.0 \mathrm{E}-03$ & - & 2.03E-03 & 2.09E-03 & - \\
\hline $\mathrm{Ca}$ & 4.85E-01 & 5.53E-01 & $4.60 \mathrm{E}-01$ & 4.99E-01 & $9.6 \%$ & 3.73E-01 & $<1.8 \mathrm{E}-02$ & $<1.8 \mathrm{E}-02$ & - & $1.02 \mathrm{E}+00$ & $1.07 \mathrm{E}+00$ & $1.02 \mathrm{E}+00$ \\
\hline $\mathrm{Cd}$ & $5.08 \mathrm{E}-01$ & 5.19E-01 & 5.13E-01 & 5.13E-01 & $1.0 \%$ & $3.40 \mathrm{E}-03$ & $<2.6 \mathrm{E}-02$ & $<2.6 \mathrm{E}-02$ & - & $1.47 \mathrm{E}-03$ & 1.63E-03 & - \\
\hline $\mathrm{Ce}$ & 3.05E-01 & 2.62E-01 & $1.76 \mathrm{E}-01$ & 2.48E-01 & $27 \%$ & $1.71 \mathrm{E}-01$ & $<2.7 \mathrm{E}-01$ & $<2.7 \mathrm{E}-01$ & - & $4.94 \mathrm{E}-02$ & 4.69E-02 & - \\
\hline $\mathrm{Cr}$ & $9.56 \mathrm{E}-02$ & $9.04 \mathrm{E}-02$ & 8.91E-02 & 9.17E-02 & $3.8 \%$ & $1.20 \mathrm{E}-02$ & $<1.1 \mathrm{E}-01$ & $<1.1 \mathrm{E}-01$ & - & 5.38E-02 & 5.12E-02 & 6.40E-02 \\
\hline $\mathrm{Cu}$ & 4.19E-02 & $4.20 \mathrm{E}-02$ & 4.17E-02 & 4.19E-02 & $0.4 \%$ & $5.00 \mathrm{E}-03$ & $<2.0 \mathrm{E}-02$ & $<2.0 \mathrm{E}-02$ & - & 3.35E-03 & $3.45 E-03$ & $3.00 \mathrm{E}-03$ \\
\hline $\mathrm{Fe}$ & $3.45 \mathrm{E}+01$ & $3.48 \mathrm{E}+01$ & $3.50 \mathrm{E}+01$ & $3.48 \mathrm{E}+01$ & $0.8 \%$ & 8.53E-02 & $4.08 \mathrm{E}+00$ & $4.88 \mathrm{E}+00$ & $4.00 \mathrm{E}+00$ & $8.96 \mathrm{E}+00$ & $8.68 \mathrm{E}+00$ & $9.79 \mathrm{E}+00$ \\
\hline Gd & 3.55E-02 & 3.41E-02 & 3.13E-02 & 3.36E-02 & $6.5 \%$ & 8.50E-03 & $<3.4 \mathrm{E}-02$ & $<3.4 \mathrm{E}-02$ & - & 7.93E-03 & 7.60E-03 & - \\
\hline $\mathrm{K}$ & $3.60 \mathrm{E}+00$ & $3.50 \mathrm{E}+00$ & $1.99 \mathrm{E}+00$ & $3.03 E+00$ & $30 \%$ & $6.29 \mathrm{E}+00$ & $1.04 \mathrm{E}+01$ & $1.12 \mathrm{E}+01$ & $1.00 \mathrm{E}+01$ & $6.10 \mathrm{E}+00$ & $6.98 \mathrm{E}+00$ & $2.26 \mathrm{E}+00$ \\
\hline $\mathrm{La}$ & 4.69E-02 & 5.06E-02 & 4.37E-02 & 4.71E-02 & $7.4 \%$ & $3.46 \mathrm{E}-02$ & $<1.0 \mathrm{E}-01$ & $<1.0 \mathrm{E}-01$ & - & $1.60 \mathrm{E}-02$ & $1.89 \mathrm{E}-02$ & - \\
\hline $\mathrm{Li}$ & 8.32E-01 & 8.47E-01 & 8.13E-01 & 8.31E-01 & $2.1 \%$ & $9.19 \mathrm{E}-02$ & $9.96 \mathrm{E}+00$ & $1.01 \mathrm{E}+01$ & $1.00 \mathrm{E}+01$ & $2.95 \mathrm{E}+00$ & $3.74 \mathrm{E}+00$ & $1.49 \mathrm{E}+00$ \\
\hline $\mathrm{Mg}$ & $1.82 \mathrm{E}+00$ & $1.80 \mathrm{E}+00$ & $1.83 E+00$ & $1.81 \mathrm{E}+00$ & $0.9 \%$ & $2.60 \mathrm{E}-03$ & $<8.0 \mathrm{E}-03$ & $1.00 \mathrm{E}-02$ & - & $4.58 \mathrm{E}-01$ & $4.38 \mathrm{E}-01$ & $5.20 \mathrm{E}-01$ \\
\hline $\mathrm{Mn}$ & $4.62 \mathrm{E}+00$ & $4.61 \mathrm{E}+00$ & $4.69 \mathrm{E}+00$ & $4.64 \mathrm{E}+00$ & $0.9 \%$ & $1.10 \mathrm{E}-03$ & $<4.0 \mathrm{E}-03$ & $9.50 \mathrm{E}-02$ & - & $1.33 \mathrm{E}+00$ & $1.29 \mathrm{E}+00$ & $1.46 \mathrm{E}+00$ \\
\hline Mo & $1.74 \mathrm{E}-01$ & 1.66E-01 & $1.46 \mathrm{E}-01$ & 1.62E-01 & $8.8 \%$ & 5.28E-02 & $<2.7 \mathrm{E}-01$ & $<2.7 \mathrm{E}-01$ & - & 4.38E-02 & 4.92E-02 & - \\
\hline
\end{tabular}


Table A- 3 - Results of the Sodium Peroxide Fusion Digestion of the OGCT Solids (Continued)

\begin{tabular}{|c|c|c|c|c|c|c|c|c|c|c|c|c|}
\hline Analyte & $\begin{array}{c}\text { 1st } \\
\text { Replicate } \\
\text { (wt\%) }\end{array}$ & $\begin{array}{c}\text { 2nd } \\
\text { Replicate } \\
\text { (wt\%) }\end{array}$ & $\begin{array}{c}\text { 3rd } \\
\text { Replicate } \\
\text { (wt\%) }\end{array}$ & $\begin{array}{c}\text { Average } \\
\text { (wt\%) }\end{array}$ & \%RSD & $\begin{array}{l}\text { Blank } \\
\text { (wt\%) }\end{array}$ & \begin{tabular}{|c|}
$1^{\text {st }}$ \\
ICP-ES Std \\
$(\mathrm{mg} / \mathrm{L})$ \\
\end{tabular} & $\begin{array}{c}2^{\text {nd }} \\
\text { ICP-ES Std } \\
\text { (mg/L) }\end{array}$ & \begin{tabular}{|c|} 
ICP-ES Std \\
Comp \\
$(\mathrm{mg} / \mathrm{L})$
\end{tabular} & $\begin{array}{c}1^{\text {st }} \\
\text { Glass Std } \\
(w t \%)\end{array}$ & $\begin{array}{c}2^{\text {nd }} \\
\text { Glass Std } \\
\text { (wt \%) }\end{array}$ & $\begin{array}{c}\text { Glass Std } \\
\text { Comp } \\
\text { (wt\%) }\end{array}$ \\
\hline $\mathrm{Ni}$ & $1.82 \mathrm{E}+00$ & $1.81 \mathrm{E}+00$ & $1.86 \mathrm{E}+00$ & $1.83 \mathrm{E}+00$ & $1.3 \%$ & $<1.9 \mathrm{E}-02$ & $<1.9 \mathrm{E}-01$ & $<1.9 \mathrm{E}-01$ & - & 7.41E-01 & 7.05E-01 & - \\
\hline $\mathrm{P}$ & 4.75E-01 & 4.53E-01 & 4.55E-01 & 4.61E-01 & $2.7 \%$ & $<5.3 \mathrm{E}-02$ & $<5.3 \mathrm{E}-01$ & $<5.3 \mathrm{E}-01$ & - & $6.45 \mathrm{E}-02$ & 5.00E-02 & $1.10 \mathrm{E}-01$ \\
\hline $\mathrm{Pb}$ & $<7.0 \mathrm{E}-02$ & $<8.9 \mathrm{E}-02$ & $<7.5 \mathrm{E}-02$ & $<7.8 \mathrm{E}-02$ & - & $<9.6 \mathrm{E}-02$ & $<9.6 \mathrm{E}-01$ & $<9.6 \mathrm{E}-01$ & - & $<3.8 \mathrm{E}-02$ & $<3.7 \mathrm{E}-02$ & - \\
\hline S & 2.64E-01 & 2.64E-01 & 2.67E-01 & 2.64E-01 & $0.8 \%$ & $<1.7 \mathrm{E}-02$ & $<1.7 \mathrm{E}-01$ & $<1.7 \mathrm{E}-01$ & - & 3.71E-02 & 3.52E-02 & - \\
\hline $\mathrm{Sb}$ & 1.63E-01 & $1.64 \mathrm{E}-01$ & $1.55 \mathrm{E}-01$ & $1.60 \mathrm{E}-01$ & $3.1 \%$ & $3.56 \mathrm{E}-02$ & $<1.0 \mathrm{E}-01$ & $<1.0 \mathrm{E}-01$ & - & $5.14 \mathrm{E}-02$ & 4.96E-02 & - \\
\hline $\mathrm{Si}$ & $7.27 \mathrm{E}+00$ & $7.45 \mathrm{E}+00$ & $7.25 \mathrm{E}+00$ & $7.32 \mathrm{E}+00$ & $1.5 \%$ & $<9.7 \mathrm{E}-02$ & $5.17 \mathrm{E}+01$ & $5.13 \mathrm{E}+01$ & $5.00 \mathrm{E}+01$ & $2.37 \mathrm{E}+01$ & $2.41 \mathrm{E}+01$ & $2.24 \mathrm{E}+01$ \\
\hline Sn & 3.80E-01 & 3.81E-01 & 3.10E-01 & 3.57E-01 & $11 \%$ & $1.62 \mathrm{E}-01$ & $<6.0 \mathrm{E}-01$ & $<6.0 \mathrm{E}-01$ & - & $1.78 \mathrm{E}-01$ & $1.82 \mathrm{E}-01$ & - \\
\hline $\mathrm{Sr}$ & $1.50 \mathrm{E}-01$ & $1.58 \mathrm{E}-01$ & $1.29 \mathrm{E}-01$ & $1.46 \mathrm{E}-01$ & $10 \%$ & 9.98E-02 & $<2.0 \mathrm{E}-02$ & $<2.0 \mathrm{E}-02$ & - & 2.18E-01 & 2.27E-01 & 3.00E-03 \\
\hline $\mathrm{Ti}$ & 3.34E-02 & 3.44E-02 & 3.34E-02 & 3.37E-02 & $1.8 \%$ & 2.90E-03 & $<6.0 \mathrm{E}-03$ & $<6.0 \mathrm{E}-03$ & - & 6.73E-01 & $6.71 \mathrm{E}-01$ & $6.90 \mathrm{E}-01$ \\
\hline $\mathrm{U}$ & 2.39E-01 & 2.43E-01 & 2.30E-01 & 2.37E-01 & $2.6 \%$ & 4.16E-02 & $<3.9 \mathrm{E}-01$ & $<3.9 \mathrm{E}-01$ & - & 2.63E-02 & 2.38E-02 & - \\
\hline V & 8.54E-03 & 8.98E-03 & $1.28 \mathrm{E}-02$ & 1.01E-02 & $23 \%$ & 7.30E-03 & $<4.0 \mathrm{E}-02$ & $<4.0 \mathrm{E}-02$ & - & $1.24 \mathrm{E}-02$ & $1.11 \mathrm{E}-02$ & - \\
\hline $\mathrm{Zn}$ & 6.61E-02 & 6.63E-02 & 6.59E-02 & 6.61E-02 & $0.3 \%$ & $1.34 \mathrm{E}-02$ & $<3.0 \mathrm{E}-02$ & $<3.0 \mathrm{E}-02$ & - & 2.22E-02 & 2.26E-02 & $1.60 \mathrm{E}-02$ \\
\hline
\end{tabular}


Table A- 4 - Concentrations of Al, Fe, Mg, Mn, Na, Ni, and Si in the Initial Supernate and Volume Corrected Supernate

\begin{tabular}{|c|c|c|}
\hline Element & $\begin{array}{c}\text { Initial OGCT } \\
\text { Supernate } \\
\text { mg/L }^{\mathbf{a}}\end{array}$ & $\begin{array}{c}\text { Volume } \\
\text { Corrected } \\
\text { OGCT } \\
\text { Supernate } \\
\text { mg/L }\end{array}$ \\
\hline $\mathbf{A l}$ & $2.61 \mathrm{E}+01$ & $6.66 \mathrm{E}+00$ \\
\hline $\mathbf{F e}$ & $1.89 \mathrm{E}+00$ & $4.83 \mathrm{E}-01$ \\
\hline $\mathbf{M g}$ & $3.85 \mathrm{E}+00$ & $9.83 \mathrm{E}-01$ \\
\hline $\mathbf{M n}$ & $8.10 \mathrm{E}+00$ & $2.07 \mathrm{E}+00$ \\
\hline $\mathbf{N a}$ & $4.16 \mathrm{E}+01$ & $1.06 \mathrm{E}+01$ \\
\hline $\mathbf{N i}$ & $8.51 \mathrm{E}-01$ & $2.17 \mathrm{E}-01$ \\
\hline $\mathbf{S i}$ & $1.18 \mathrm{E}+01$ & $3.02 \mathrm{E}+00$ \\
\hline
\end{tabular}

${ }^{\mathrm{a}}$ Average of three values

${ }^{\mathrm{b}}$ Initial concentrations divided by $(470 \mathrm{~mL} / 120 \mathrm{~mL})$ to obtain volume correction. 
WSRC-TR-2005-00141

Revision 0

Table A- 5 - Supernate Data for the 12 wt.\% and 50 wt. \% Test Cases

\begin{tabular}{|c|c|c|c|c|c|}
\hline Element & $\begin{array}{c}\text { OGCT Conc. Prior } \\
\text { to Addition of } \\
\mathrm{HNO}_{3} \\
(\mathrm{mg} / \mathrm{L})^{\mathrm{a}}\end{array}$ & $\begin{array}{c}\text { Time Zero (After } \\
\mathrm{HNO}_{3} \text { is Added) } \\
(\mathrm{mg} / \mathrm{L})^{\mathrm{b}}\end{array}$ & $\begin{array}{l}\text { Time }-2 \\
\text { Hours } \\
(\mathrm{mg} / \mathrm{L})^{\mathrm{b}}\end{array}$ & $\begin{array}{l}\text { Time }-8 \\
\text { Hours } \\
(\mathrm{mg} / \mathrm{L})^{\mathrm{b}}\end{array}$ & $\begin{array}{l}\text { Time }-24 \\
\text { Hours } \\
(\mathrm{mg} / \mathrm{L})^{\mathrm{b}}\end{array}$ \\
\hline \multicolumn{6}{|l|}{$\begin{array}{c}12 \text { wt. \% } \\
\text { HNO }_{3} \text { Test }\end{array}$} \\
\hline $\mathrm{Al}$ & $\begin{array}{c}6.66 \\
(0.0300 .38)\end{array}$ & $\begin{array}{c}8.93 \\
(0.024,0.27) \\
\end{array}$ & $\begin{array}{c}11.00 \\
(0.080,0.73)\end{array}$ & $\begin{array}{c}13.90 \\
(0.002,0.01)\end{array}$ & $\begin{array}{c}18.30 \\
(0.088,0.48)\end{array}$ \\
\hline $\mathrm{Fe}$ & $\begin{array}{c}0.48 \\
(0.005,1.1)\end{array}$ & $\begin{array}{c}6.13 \\
(0.036,0.59)\end{array}$ & $\begin{array}{c}46.60 \\
(0.288,0.62)\end{array}$ & $\begin{array}{c}85.50 \\
(0.073,0.09)\end{array}$ & $\begin{array}{c}129.00 \\
(0.613,0.48)\end{array}$ \\
\hline $\mathrm{Mg}$ & $\begin{array}{c}0.98 \\
(0.014,1.4) \\
\end{array}$ & $\begin{array}{c}2.26 \\
(0.018,0.82) \\
\end{array}$ & $\begin{array}{c}5.51 \\
(0.025,0.45) \\
\end{array}$ & $\begin{array}{c}11.70 \\
(0.020,0.17)\end{array}$ & $\begin{array}{c}15.40 \\
(0.090,0.58)\end{array}$ \\
\hline $\mathrm{Mn}$ & $\begin{array}{c}2.07 \\
(0.026,1.3)\end{array}$ & $\begin{array}{c}2.69 \\
(0.018,0.68)\end{array}$ & $\begin{array}{c}11.00 \\
(0.060,0.54)\end{array}$ & $\begin{array}{c}18.90 \\
(0.016,0.09)\end{array}$ & $\begin{array}{c}24.60 \\
(0.084,0.34)\end{array}$ \\
\hline $\mathrm{Na}$ & $\begin{array}{c}10.63 \\
(0.029,0.28)\end{array}$ & $\begin{array}{c}13.40 \\
(0.038,0.28)\end{array}$ & $\begin{array}{c}13.50 \\
(0.021,0.15) \\
\end{array}$ & $\begin{array}{c}15.20 \\
(0.284,1.9) \\
\end{array}$ & $\begin{array}{c}14.40 \\
(0.090,0.63)\end{array}$ \\
\hline $\mathrm{Ni}$ & $\begin{array}{c}0.22 \\
(0.0006,0.30\end{array}$ & $\begin{array}{c}0.28 \\
(0.025,8.8) \\
\end{array}$ & $\begin{array}{c}2.35 \\
(0.049,2.1) \\
\end{array}$ & $\begin{array}{c}5.00 \\
(0.034,0.68) \\
\end{array}$ & $\begin{array}{c}7.94 \\
(0.074,0.94) \\
\end{array}$ \\
\hline Si & $\begin{array}{c}3.02 \\
(0.053,1.8)\end{array}$ & $\begin{array}{c}3.96 \\
(0.012,0.31) \\
\end{array}$ & $\begin{array}{c}5.04 \\
(0.007,0.14) \\
\end{array}$ & $\begin{array}{c}6.32 \\
(0.005,0.08) \\
\end{array}$ & $\begin{array}{c}8.00 \\
(0.094,1.2) \\
\end{array}$ \\
\hline \multicolumn{6}{|l|}{$\begin{array}{c}50 \text { wt. \% } \\
\text { HNO }_{3} \text { Test }\end{array}$} \\
\hline $\mathrm{Al}$ & $\begin{array}{c}6.66 \\
(0.0300 .38)\end{array}$ & $\begin{array}{c}9.23 \\
(0.031,0.34)\end{array}$ & $\begin{array}{c}13.90 \\
(0.048,0.34)\end{array}$ & $\begin{array}{c}17.90 \\
(0.024,0.14)\end{array}$ & $\begin{array}{c}22.90 \\
(0.002,0.01)\end{array}$ \\
\hline $\mathrm{Fe}$ & $\begin{array}{c}0.48 \\
(0.005,1.1)\end{array}$ & $\begin{array}{c}34.00 \\
(0.366,1.1)\end{array}$ & $\begin{array}{c}112.00 \\
(0.202,0.18)\end{array}$ & $\begin{array}{c}169.00 \\
(0.229,0.14) \\
\end{array}$ & $\begin{array}{c}226.00 \\
(2.99,1.3)\end{array}$ \\
\hline $\mathrm{Mg}$ & $\begin{array}{c}0.98 \\
(0.014,1.4)\end{array}$ & $\begin{array}{c}4.00 \\
(0.066,1.6)\end{array}$ & $\begin{array}{c}13.30 \\
(0.078,0.58)\end{array}$ & $\begin{array}{c}19.80 \\
(0.224,1.1)\end{array}$ & $\begin{array}{c}24.40 \\
(0.299,1.2)\end{array}$ \\
\hline $\mathrm{Mn}$ & $\begin{array}{c}2.07 \\
(0.026,1.3)\end{array}$ & $\begin{array}{c}7.93 \\
(0.092,1.2)\end{array}$ & $\begin{array}{c}27.50 \\
(0.077,0.28) \\
\end{array}$ & $\begin{array}{c}39.70 \\
(0.153,0.38) \\
\end{array}$ & $\begin{array}{c}49.10 \\
(0.598,1.2) \\
\end{array}$ \\
\hline $\mathrm{Na}$ & $\begin{array}{c}10.63 \\
(0.029,0.28) \\
\end{array}$ & $\begin{array}{c}13.50 \\
(0.051,0.38) \\
\end{array}$ & $\begin{array}{c}14.00 \\
(0.178,1.3)\end{array}$ & $\begin{array}{c}14.50 \\
(0.020,0.14)\end{array}$ & $\begin{array}{c}17.00 \\
(0.097,0.57) \\
\end{array}$ \\
\hline $\mathrm{Ni}$ & $\begin{array}{c}0.22 \\
(0.0006,0.30\end{array}$ & $\begin{array}{c}1.46 \\
(0.009,0.59)\end{array}$ & $\begin{array}{c}6.83 \\
(0.033,0.50)\end{array}$ & $\begin{array}{c}10.50 \\
(0.054,0.51)\end{array}$ & $\begin{array}{c}13.90 \\
(0.150,1.1)\end{array}$ \\
\hline $\mathrm{Si}$ & $\begin{array}{c}3.02 \\
(0.053,1.8)\end{array}$ & $\begin{array}{c}6.07^{\mathrm{C}} \\
(0.993,16) \\
\end{array}$ & $\begin{array}{c}13.70^{\mathrm{c}} \\
(4.73,35)\end{array}$ & $\begin{array}{c}17.50 \\
(1.80,10)\end{array}$ & $\begin{array}{c}17.40 \\
(1.48,8.5)\end{array}$ \\
\hline
\end{tabular}

${ }^{a}$ Average of three results. Standard deviation and \% RSD are in parentheses, respectively.

${ }^{\mathrm{b}}$ Average of two results. Standard deviation and \% RSD are in parentheses, respectively.

${ }^{\mathrm{c}}$ Precision of the Silica results for these samples is not very good. The ICP-ES standard submitted with these results indicated that the Si was off by $9 \%$, but within the $10 \%$ limit. Since only two samples were submitted, the average of both samples was used. 
WSRC-TR-2005-00141

Revision 0

\section{APPENDIX B}

CONTAINED SCANNING ELECTRON MICROSCOPY RESULTS FOR THE OGCT SAMPLE 


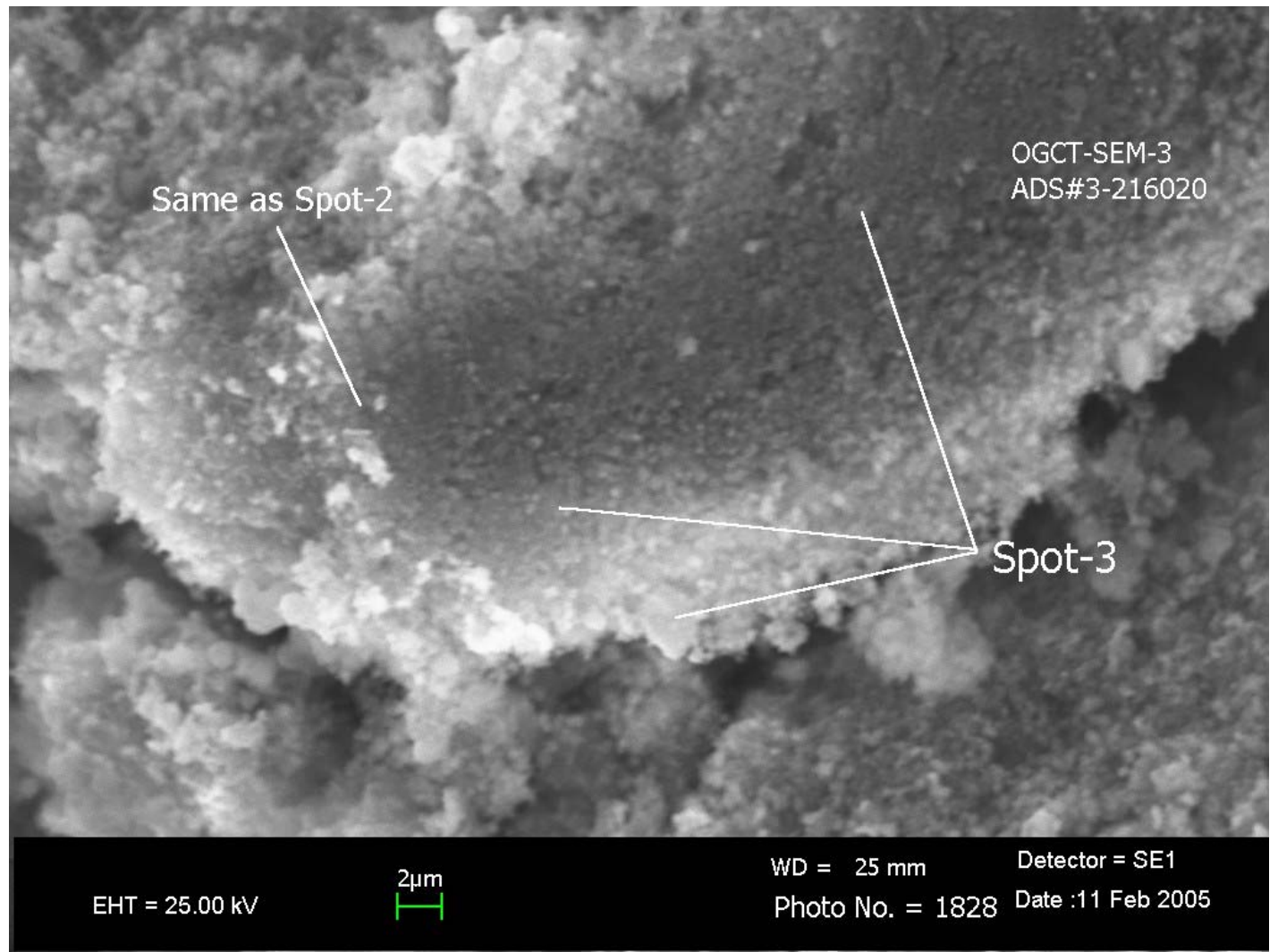

Figure B - 1 CSEM Picture of the OGCT Solids (Magnification of 2000x)

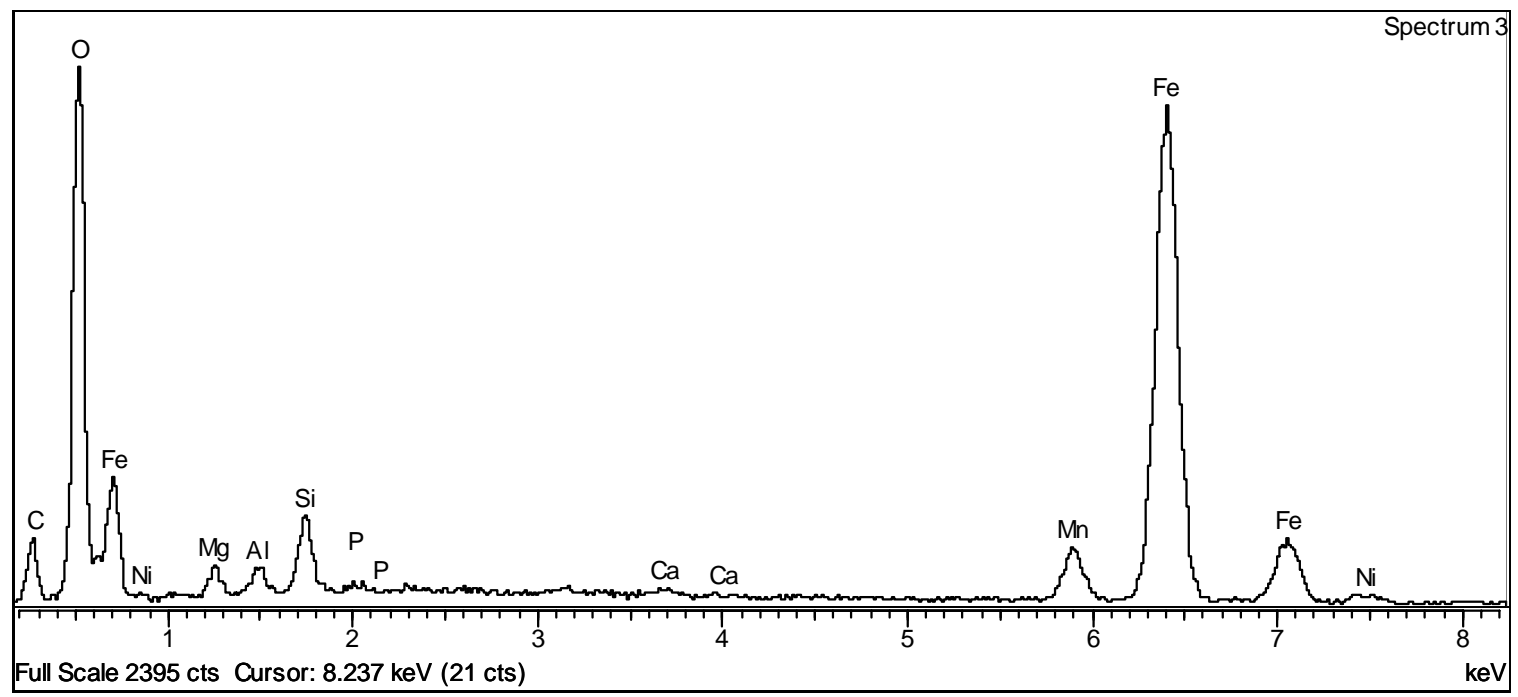

Figure B - 2 Spectrum for Spot 1 Identified in Figure B - 1 for the OGCT Solids 
WSRC-TR-2005-00141

Revision 0

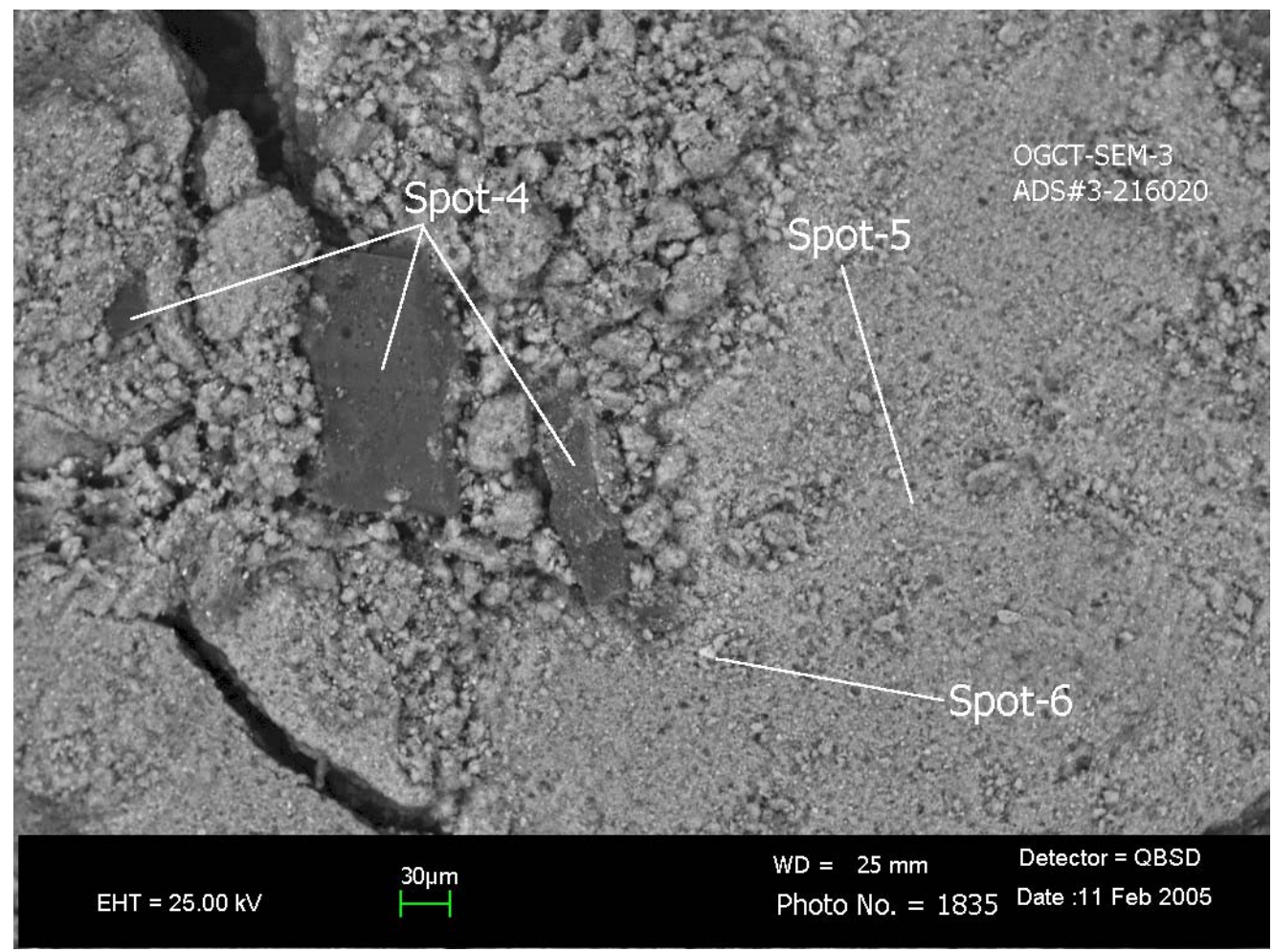

Figure B - 3 CSEM Picture of the OGCT Solids (Magnification of 150x)

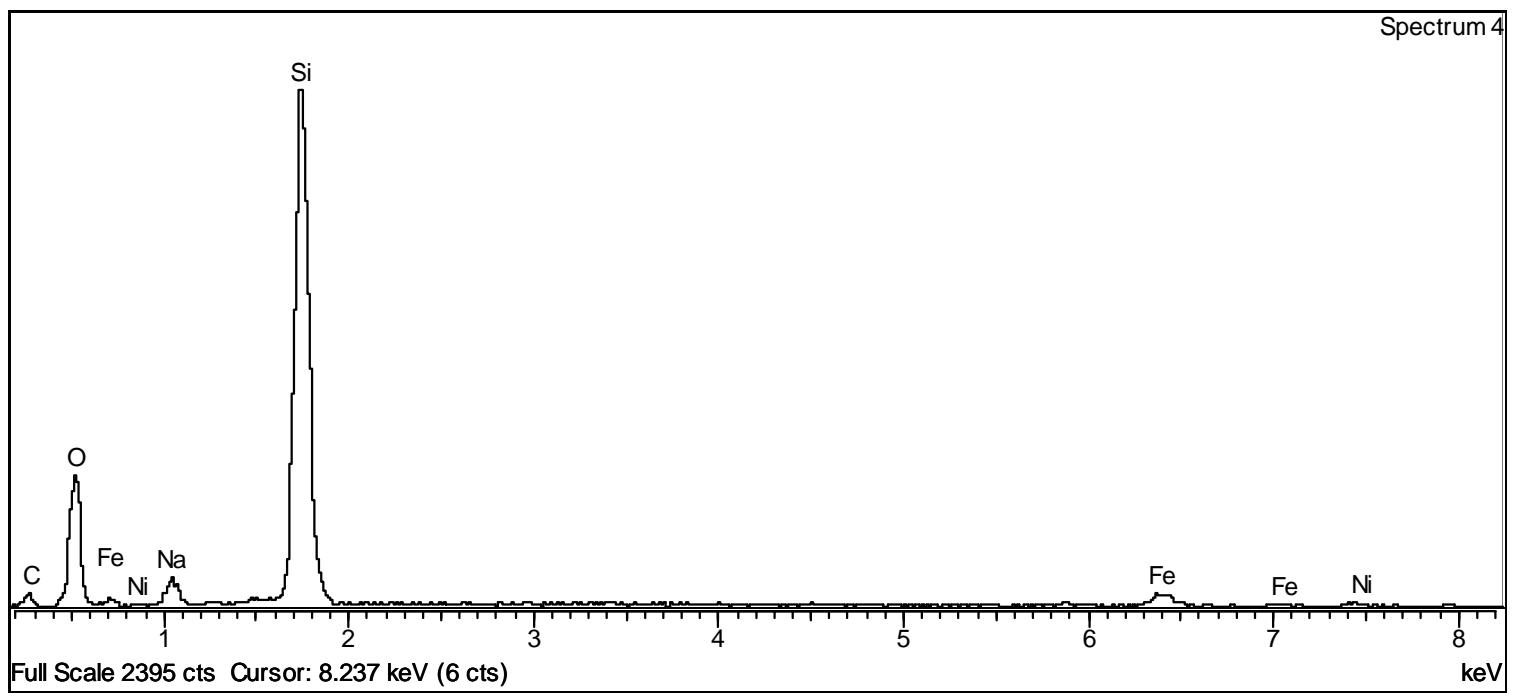

Figure B - 4 Spectrum for Spot 4 Identified in Figure B - 3 for the OGCT Solids 
WSRC-TR-2005-00141

Revision 0

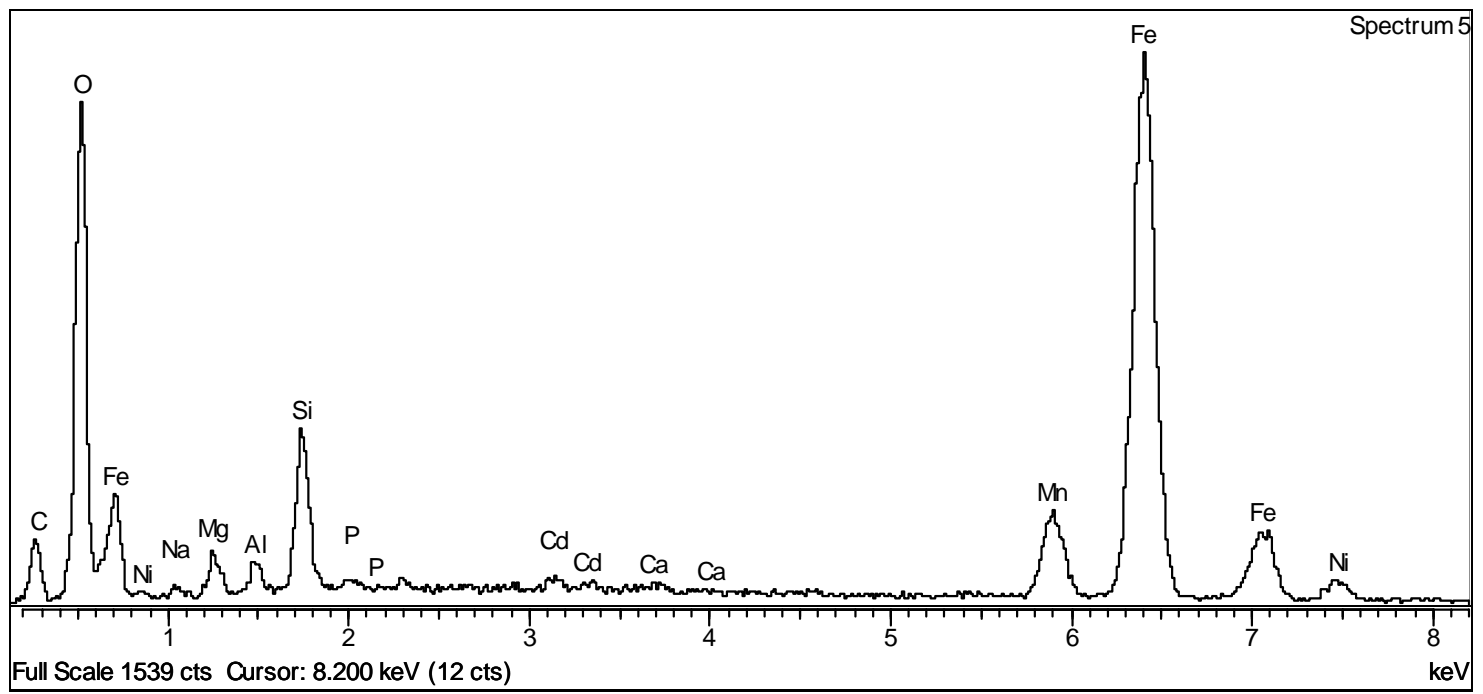

Figure B - 5 Spectrum for Spot 5 Identified in Figure B - 3 for the OGCT Solids

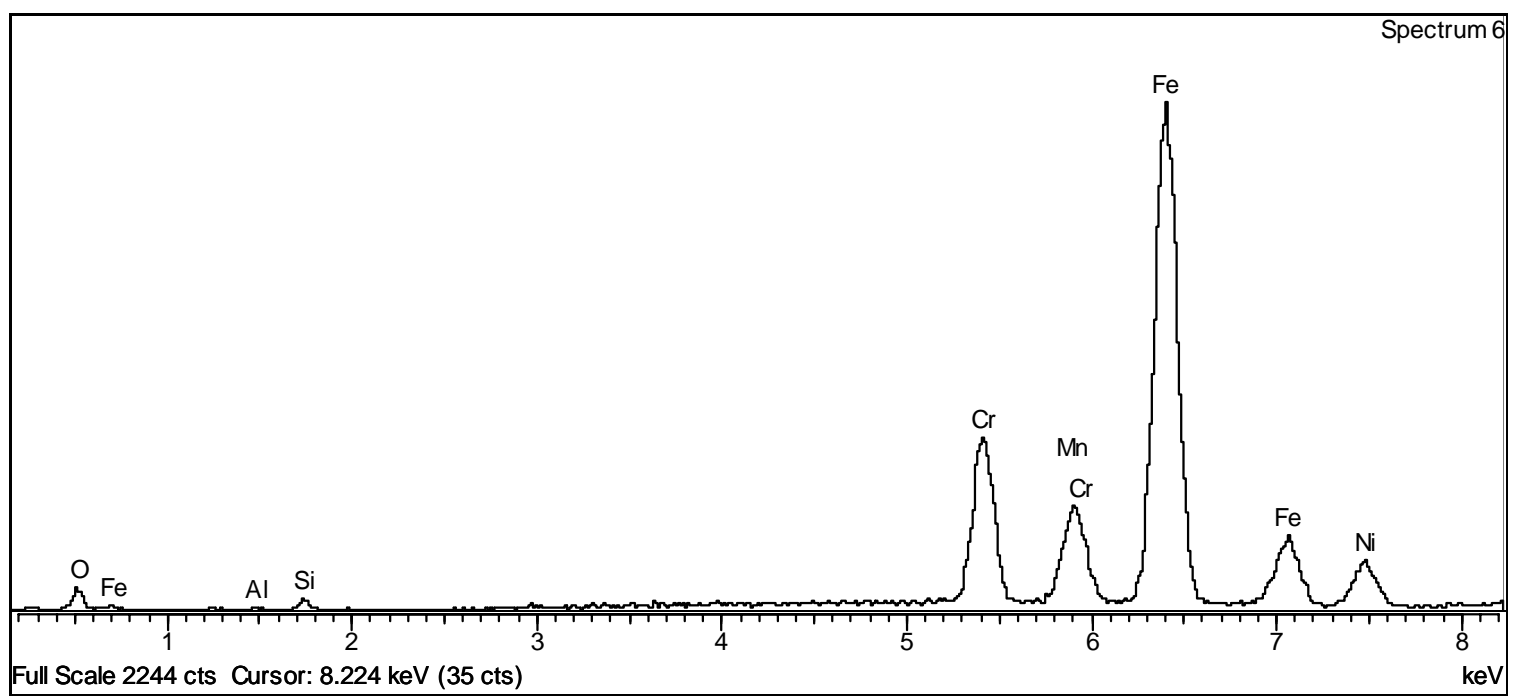

Figure B - 6 Spectrum for Spot 6 Identified in Figure B - 3 for the OGCT Solids 


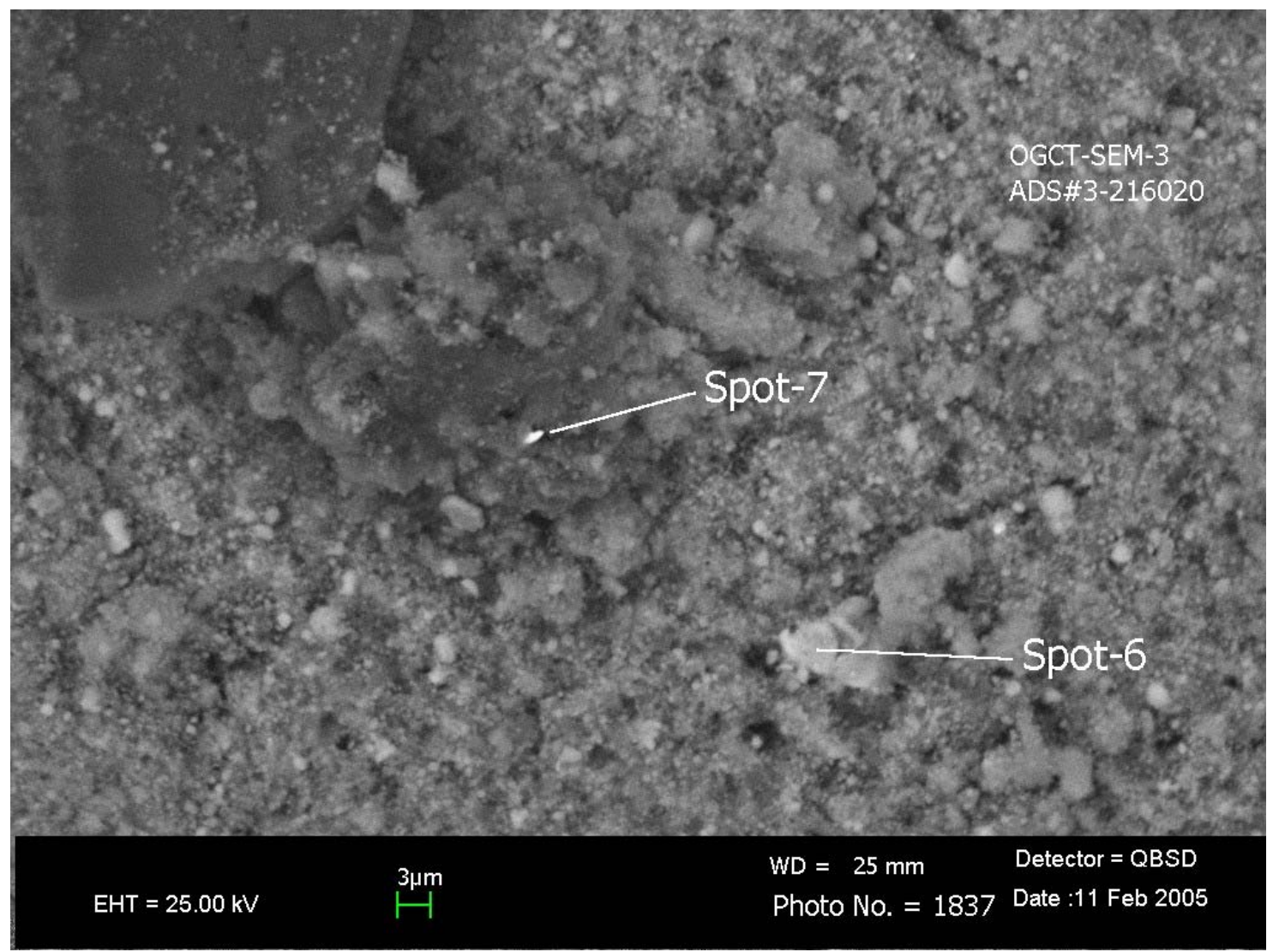

Figure B - 7 CSEM Picture of the OGCT Solids (Magnification of 1000x)

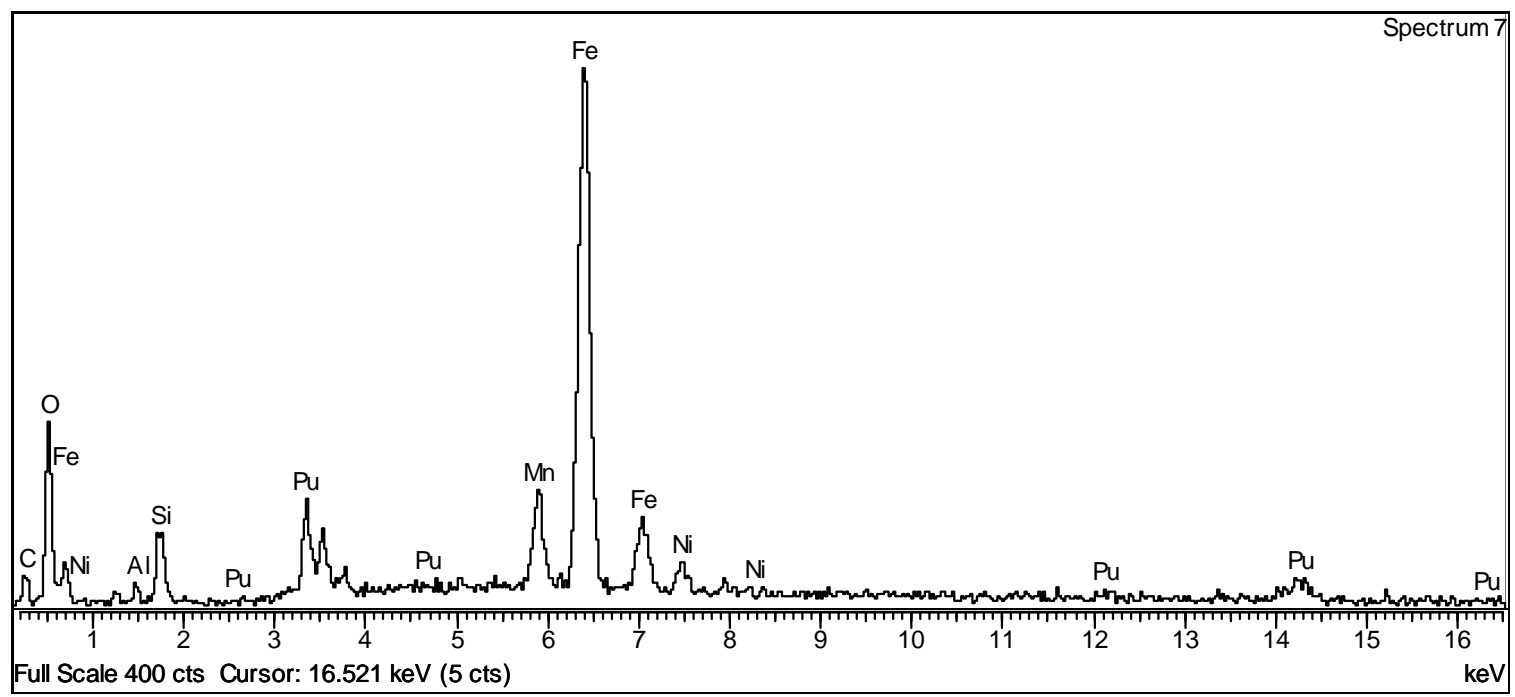

Figure B - 8 Spectrum for Spot 7 Identified in Figure B - 7 for the OGCT Solids 
WSRC-TR-2005-00141

Revision 0

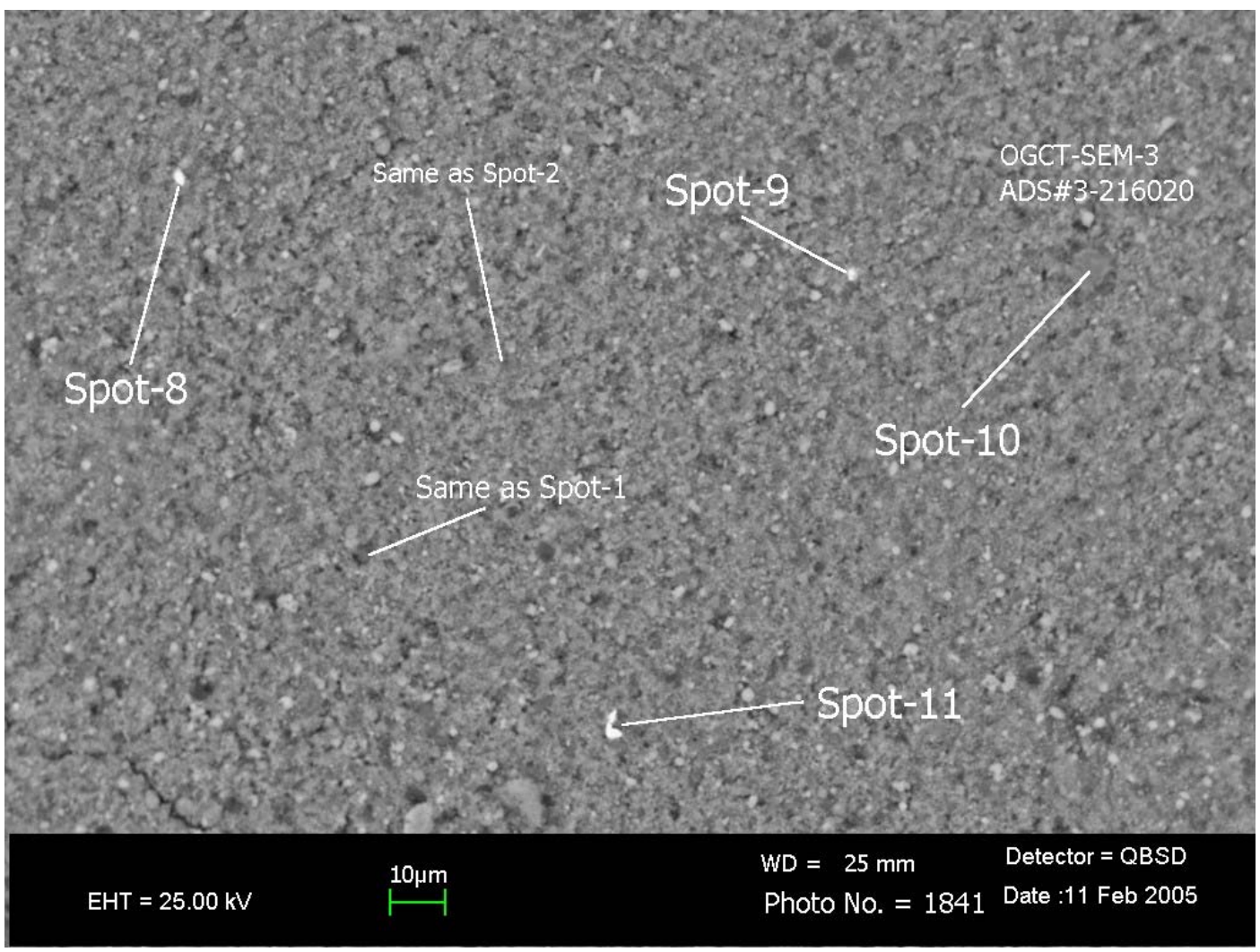

Figure B - 9 CSEM Picture of the OGCT Solids (Magnification of 500x)

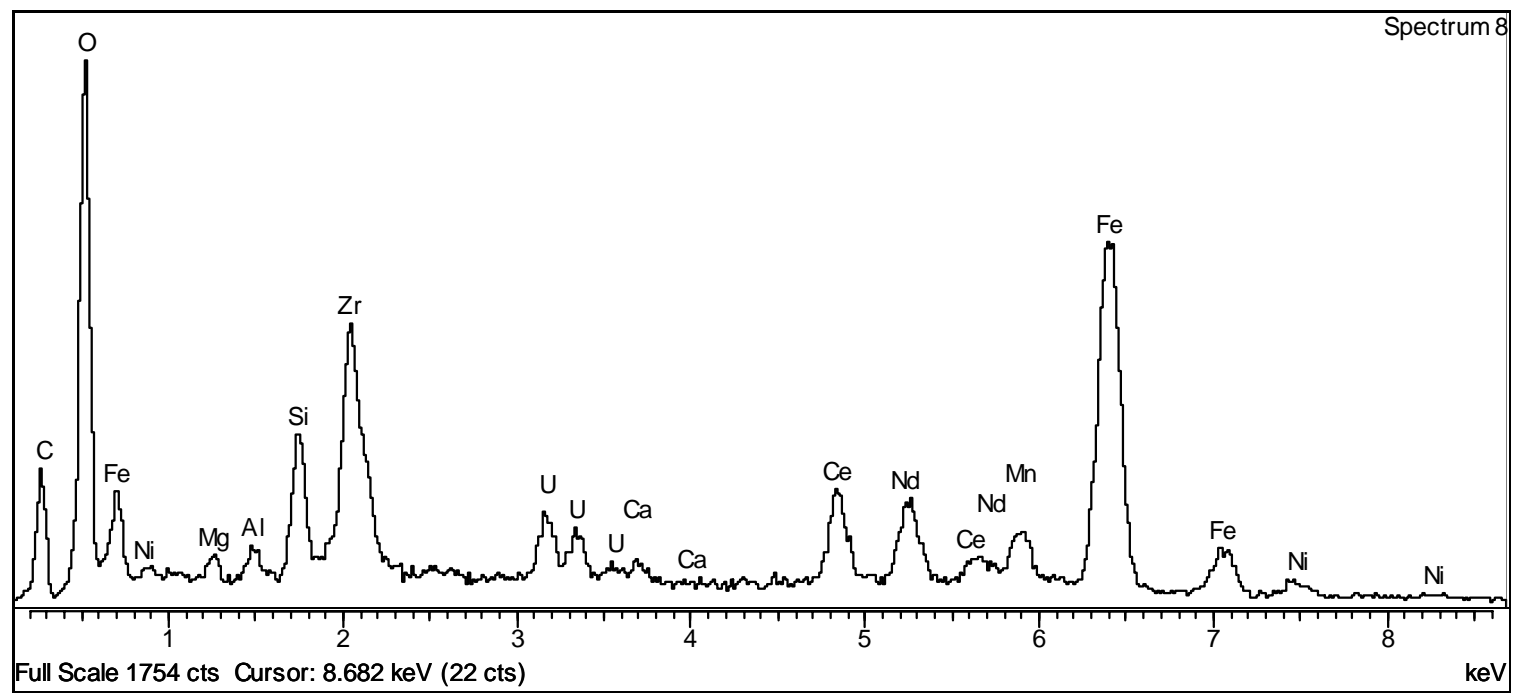

Figure B - 10 Spectrum for Spot 8 Identified in Figure B - 9 for the OGCT Solids 


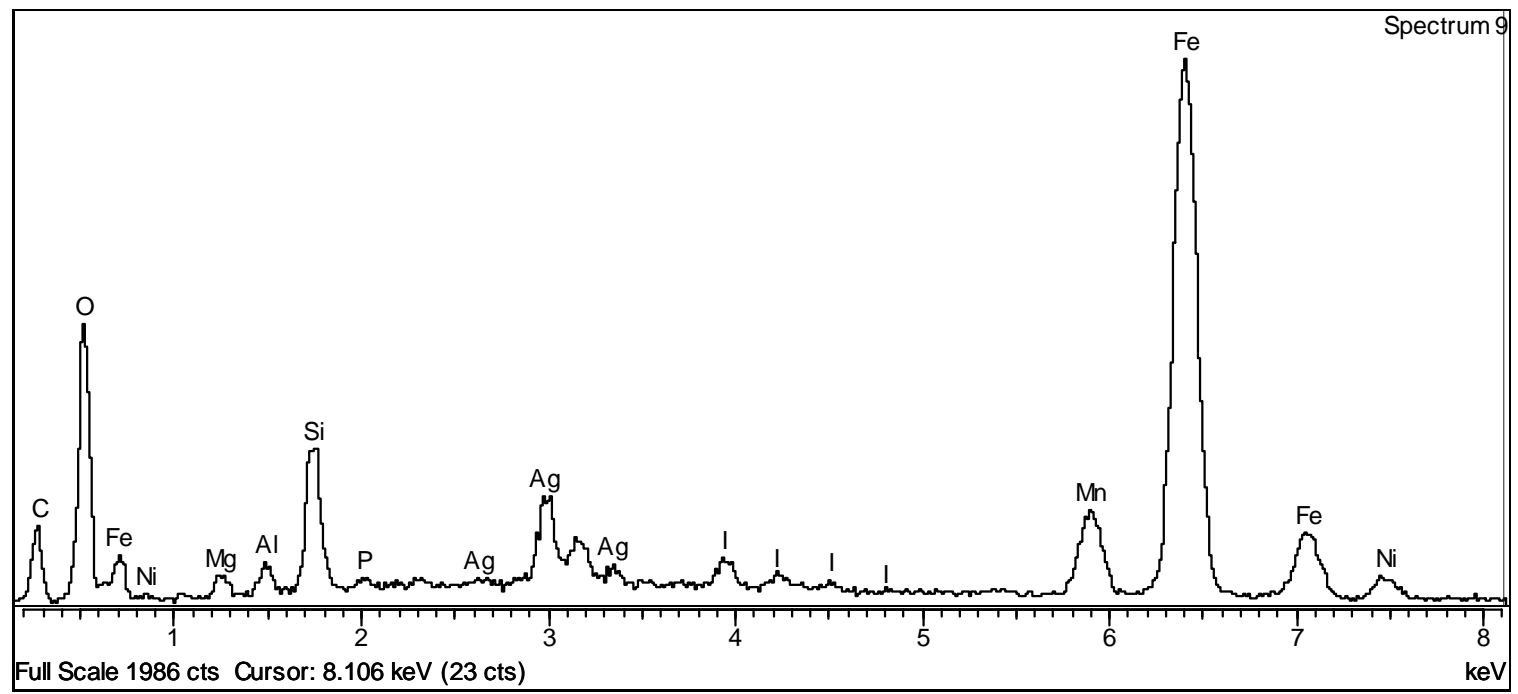

Figure B - 11 Spectrum for Spot 9 Identified in Figure B - 9 for the OGCT Solids

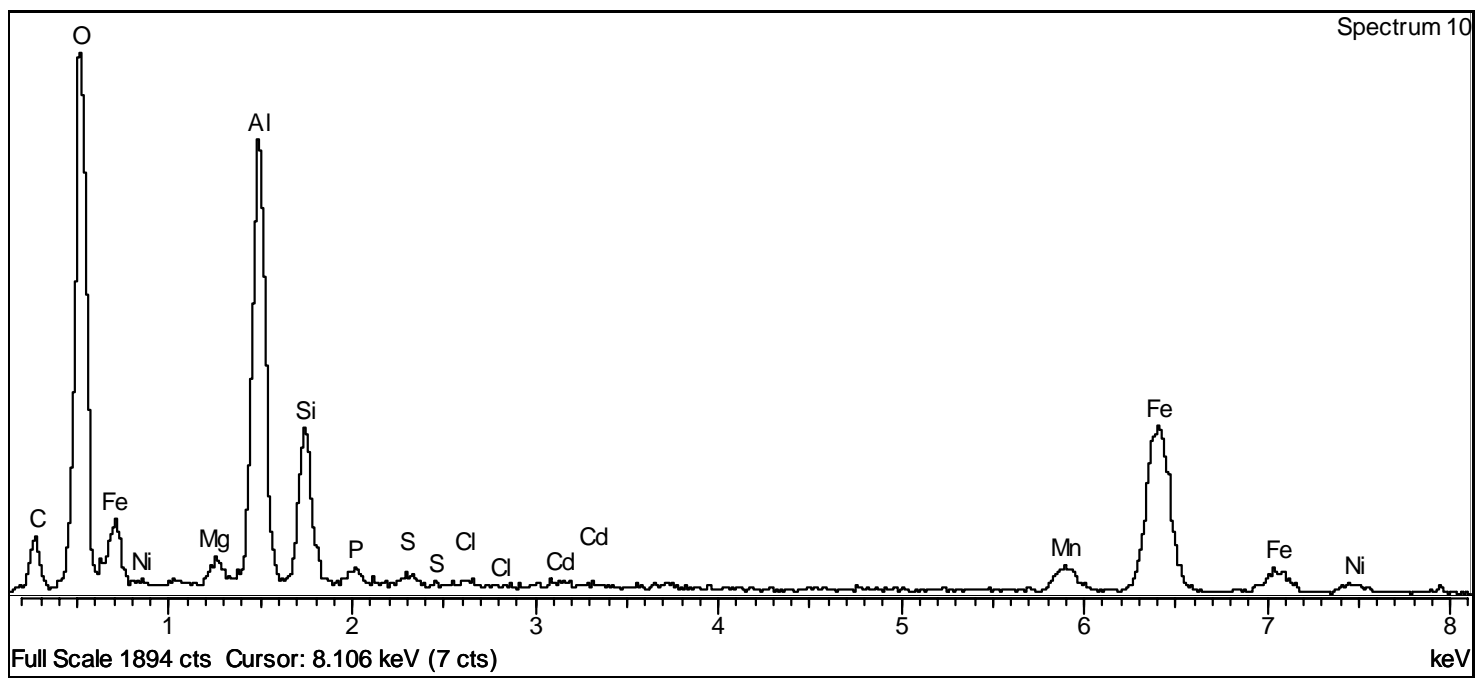

Figure B - 12 Spectrum for Spot 10 Identified in Figure B - 9 for the OGCT Solids 
WSRC-TR-2005-00141

Revision 0

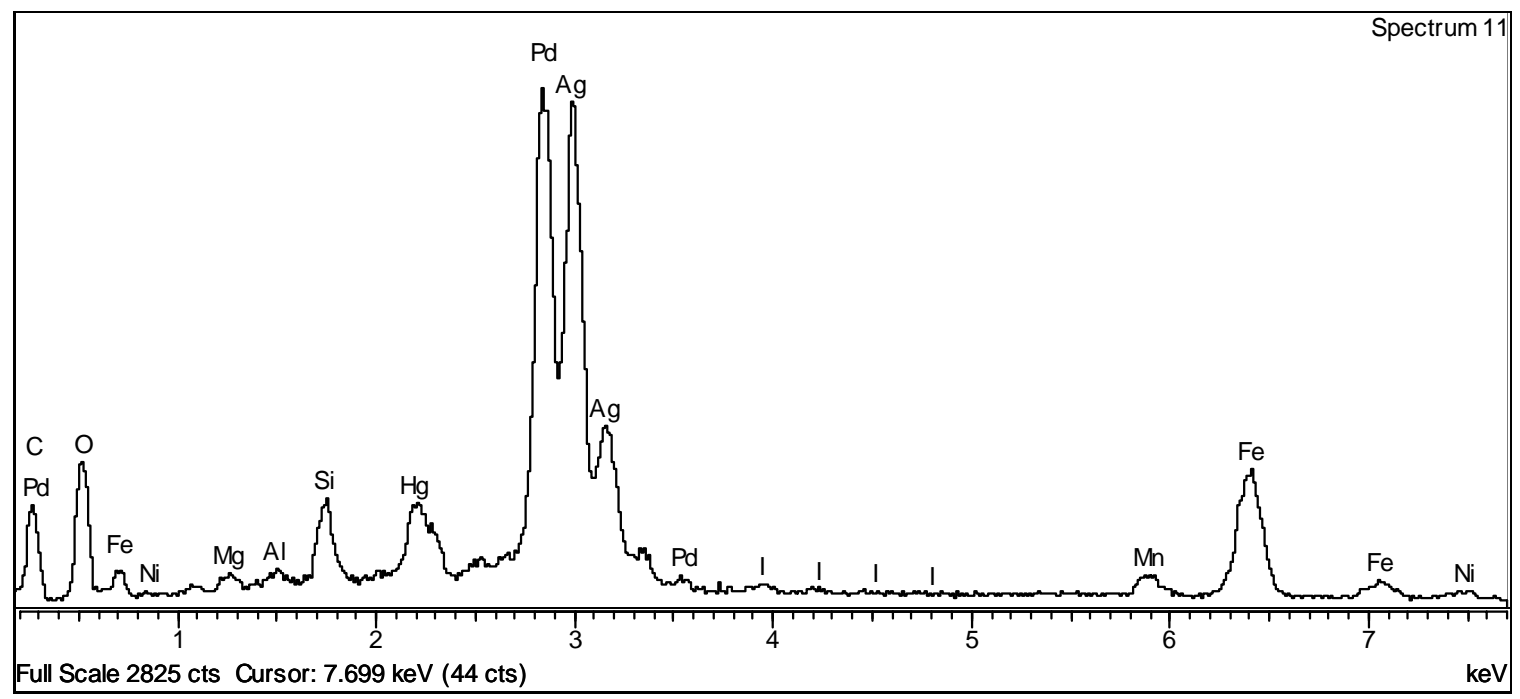

Figure B - 13 Spectrum for Spot 11 Identified in Figure B - 9 for the OGCT Solids 


\section{Distribution:}

E. W. Holtzscheiter, 773-A

D. A. Crowley, 999-W

S. L. Marra, 999-W

T. B. Calloway, 999-W

N. E. Bibler, 773-A

C. M. Jantzen, 773-A

J. R. Harbour, 773-42A

G. C. Wicks, 773-A

T. B. Edwards, 773-42A

D. K. Peeler, 999-W

M. E. Stone, 999-W

C. C. Herman, 773-42A

J. M. Pareizs, 773-A

D. C. Koopman, 773-42A

C. J. Bannochie, 773-42A

M. A. Baich, 999-W

M. S. Miller, 704-S

J. E. Occhipinti, 704-S

R. M. Hoeppel, 704-27S

H. H. Elder, 766-H

J. F. Iaukea, 704-30S

V.R. Buch, 704-30S

W. L. Melton, 704-28S

R. N. Mahannah, 704-28S 